Supporting information:

\title{
Rigidified DNA triangle-protected molecular beacon from endogenous nuclease digestion for monitoring microRNA expression in living cell
}

\author{
Congcong Li, ${ }^{\mathrm{a}}$ Mengxue Luo, ${ }^{\mathrm{a}}$ Jue Wang, ${ }^{\mathrm{a}, \mathrm{b}}$ Huimin Niu, ${ }^{\mathrm{a}}$ Zhifa Shen ${ }^{\mathrm{a}, \mathrm{b}}$ and Zai-Sheng $\mathrm{Wu}^{\mathrm{a}, *}$ \\ ${ }^{a}$ Cancer Metastasis Alert and Prevention Center, Fujian Provincial Key Laboratory of Cancer \\ Metastasis Chemoprevention and Chemotherapy, National \& Local Joint Biomedical Engineering \\ Research Center on Photodynamic Technologies, State Key Laboratory of Photocatalysis on Energy \\ and Environment, College of Chemistry, Fuzhou University, Fuzhou, 350002, China \\ ${ }^{b}$ Key Laboratory of Laboratory Medicine, Ministry of Education of China, and Zhejiang Provincial \\ Key Laboratory of Medical Genetics, School of Laboratory Medicine and Life Sciences, Wenzhou \\ Medical University, Wenzhou, 325035, China \\ *Corresponding Author: Email, wuzaisheng@163.com (Z.S. Wu)
}




\section{Supplementary experimental procedures}

\section{Gel electrophoresis.}

The gel electrophoresis analysis was performed on an electrophoresis instrument (BIO-RAD, USA). The gel image was recorded using a ChemiDoc XRS Imaging system (Bio-RAD, U.S.A.).

Characterization of the stepwise assembly: The assembled products were analyzed by $6 \%$ native polyacrylamide gel electrophoresis (nPAGE) in $0.5 \times$ TBE buffer (45 $\mathrm{mM}$ Tris, $45 \mathrm{mM}$ boric acid, $1 \mathrm{mM}$ EDTA, $\mathrm{pH}=7.9$ ) at $60 \mathrm{~V}$ for $60 \mathrm{~min}$. During preparing the controls, $1 \times \mathrm{TE}$ buffer was used instead of the corresponding DNA components. The loading sample was prepared via mixing $10 \mu \mathrm{L}$ of reaction solution with $2 \mu \mathrm{L}$ of $6 \times$ loading buffer.

Exploration of biological stability: Tri-MB $(25 \mu \mathrm{L}, 0.4 \mu \mathrm{M})$ and $\mathrm{MB}$ as control (1 $\mu \mathrm{L}, 10 \mu \mathrm{M}$, adjusted to $25 \mu \mathrm{L}$ by $1 \times \mathrm{TE}$ buffer) were incubated with $2 \mathrm{U} / \mathrm{mL}$ DNase I at $37^{\circ} \mathrm{C}$ for $0,30,60,90$ or $120 \mathrm{~min}$. Then, the resulting solution was heated to $75^{\circ} \mathrm{C}$ for $10 \mathrm{~min}$ to terminate the enzymatic digestion. The products were analyzed by denatured polyacrylamide gel electrophoresis (dPAGE, 10\%) in $0.5 \times$ TBE buffer at $30 \mathrm{~mA}$ for $20 \mathrm{~min}$. The loading sample was prepared via mixing $10 \mu \mathrm{L}$ of reaction solution with $10 \mu \mathrm{L}$ of $2 \times$ loading buffer.

\section{Fluorescence detection.}

The fluorescence measurements were performed on F-7000 fluorescence spectrometer (Hitachi, Japan) with PMT detector voltage of $600 \mathrm{~V}$. The excitation wavelength of $492 \mathrm{~nm}($ slit=5 nm) was used, and the emission wavelength range of 505-600 nm was collected at the scan rate of $240 \mathrm{~nm} / \mathrm{min}$ with an excitation and emission slit width of $5.0 \mathrm{~nm}$.

The feasibility for target detection: Tri-MB $(25 \mu \mathrm{L}, 0.4 \mu \mathrm{M}$, adjusting the volume to $199 \mu \mathrm{L}$ with $1 \times \mathrm{TE}$ buffer) was incubated with target species $(1 \mu \mathrm{L}, 10 \mu \mathrm{M})$ or the equal volume of $1 \times \mathrm{TE}$ buffer as blank at $37^{\circ} \mathrm{C}$ for $2 \mathrm{~h}$. The different in fluorescence intensity between two solutions was used to evaluate the feasibility for miRNA target detection.

Quantitative detection capability: Tri-MB $(25 \mu \mathrm{L}, 0.4 \mu \mathrm{M})$ was mixed with variable concentrations of target (final concentration: $0.1 \sim 100 \mathrm{nM}$ ) or blank. Then, the total volume was adjusted to $200 \mu \mathrm{L}$ with $1 \times \mathrm{TE}$ buffer. After the $2 \mathrm{~h}$ of incubation at $37{ }^{\circ} \mathrm{C}$, the fluorescence spectra of FAM were collected with the excitation wavelength of $492 \mathrm{~nm}$ (slit=5 nm), emission wavelength range of 505-600 nm (slits $=5 \mathrm{~nm}$ ) and scanning speed of $240 \mathrm{~nm} / \mathrm{min}$.

Real-time fluorescence monitoring: The Tri-MB is capable of avoiding the false-positive signal. Tri-MB $(25 \mu \mathrm{L}, 0.4 \mu \mathrm{M}$, adjusting the volume to $198 \mu \mathrm{L}$ with $1 \times \mathrm{TE}$ buffer) and $\mathrm{MB}(1 \mu \mathrm{L}, 10 \mu \mathrm{M}$, adjusting the volume to $198 \mu \mathrm{L}$ with $1 \times \mathrm{TE}$ buffer) were separately incubated with DNase I ( $2 \mu \mathrm{L}, 200 \mathrm{U} / \mathrm{mL})$ or an equal volume of $1 \times \mathrm{TE}$ buffer at $37{ }^{\circ} \mathrm{C}$ for $10 \mathrm{~min}$. Once DNase I (or $1 \times \mathrm{TE}$ buffer) was added, the fluorescence increase of FAM was immediately monitored within 10 min. The excitation wavelength was set as $492 \mathrm{~nm}$ and emission wavelength was $520 \mathrm{~nm}$. 


\section{Confocal microscopy imaging.}

Sensing the difference in miRNA expression level: For the confocal fluorescence imaging of reduced expression levels of miRNA-21 in living cells, MCF-7 cells were incubated with $10 \mathrm{nM} \mathrm{E} 2$ at $37^{\circ} \mathrm{C}$ for $24 \mathrm{~h}$ in advance. Then, the $\mathrm{E}_{2}$-treated MCF-7 cells were incubated with Apt-Tri-MB (final concentration: $50 \mathrm{nM}$ ) according to the same procedure as that adopted for the confocal fluorescence imaging of normal MCF-7 cells.

Universality of Apt-Tri-MB: Apt-Tri-MB-7a was assembled as described in the section of 'Preparation of Tri-MB', but MB-7a was used instead of MB. To perform the cellular imaging for screening miRNA, the MCF-7 cells were incubated with Apt-Tri-MB-7a (final concentration: $50 \mathrm{nM}$ ) under identical conditions to those adopted for the Apt-Tri-MB-based cellular imaging. 


\section{Supplementary Tables}

Table S1. The oligonucleotides designed in the current study. ${ }^{\text {a }}$

\begin{tabular}{|c|c|}
\hline Names & Sequences (from 5' to 3') \\
\hline Strand a-Cy5 (Sa-Cy5) & $\begin{array}{l}\text { GAAGAGCCGCCATAGTAGAACATTCCTAAGTCTGAAACAT } \\
\text { TACAGCTTGCTACA } C / C y 5 /\end{array}$ \\
\hline Strand a-FAM (Sa-F) & $\begin{array}{l}\text { GAAGAGCCGCCATAGTAGAACATTCCTAAGTCTGAAACAT } \\
\text { TACAGCTTGCTACAC/FAM/ }\end{array}$ \\
\hline Strand b (Sb) & $\begin{array}{l}\text { GTGTAGCAAGCTGTAATAGATGCGAGGGTCCAATACCATAT } \\
\text { CACCAGGCAGTTGA }\end{array}$ \\
\hline Strand b-Cy3 (Sb-Cy3) & $\begin{array}{l}\text { /Cy3/GTGTAGCAAGCTGTAATAGATGCGAGGGTCCAATACC } \\
\text { ATATCACCAGGCAGTTGA }\end{array}$ \\
\hline Strand c (Sc) & TACTATGGCGGCTCTTCTTTTTTTCAACTGCCTGGTGATA \\
\hline Strand c-AS1411 (Sc-Apt) & $\begin{array}{l}\text { GGTGGTGGTGGTTGTGGTGGTGGTGGTTTTTTACTATGGCG } \\
\text { GCTCTTCTTTTTTTCAACTGCCTGGTGATA }\end{array}$ \\
\hline AS1411 (Apt) & $\begin{array}{l}\text { GGTGGTGGTGGTTGTGGTGGTGGTGGTTTTTTTCCCAC } \\
\text { GTAGTGTCGT }\end{array}$ \\
\hline $\begin{array}{l}\text { Strand c-random sequence } \\
\text { (Sc-rApt) }\end{array}$ & $\begin{array}{l}\text { GAGAACCTGAGTCAGTATTGCGGAGATTTTTTACTATGGCG } \\
\text { GCTCTTCTTTTTTTCAACTGCCTGGTGATA }\end{array}$ \\
\hline Strand d (Sd) & $\begin{array}{l}\text { TTCAGACTTAGGAATGTGCTTCCCACGTAGTGTCGTTTGTA } \\
\text { TTGGACCCTCGCAT }\end{array}$ \\
\hline Strand e $(\mathrm{Se})$ & $\begin{array}{l}\text { GGTGATACGTCTACTATTCTTCCCACGTAGTGTCGTTTGTAT } \\
\text { TGGACCCTCGCAT }\end{array}$ \\
\hline Strand $\mathrm{f}(\mathrm{Sf})$ & $\begin{array}{l}\text { TTCAGACTTAGGAATGTGTCTGAAATTTATCACCCGCCATA } \\
\text { GTAGACGTATCACC }\end{array}$ \\
\hline Strand $g(\mathrm{Sg})$ & $\begin{array}{l}\text { CGGGTGATAAATTTCAGTTTTACTATGGCGGCTCTTCTTTTC } \\
\text { AACTGCCTGGTGATA }\end{array}$ \\
\hline Strand g-AS1411 (Sg-Apt) & $\begin{array}{l}\text { GGTGGTGGTGGTTGTGGTGGTGGTGGTTTTTCGGGTGA } \\
\text { TAAATTTCAGTTTTACTATGGCGGCTCTTCTTTTCAACTGCC } \\
\text { TGGTGATA }\end{array}$ \\
\hline Molecular Beacon (MB) & $\begin{array}{l}\text { A/FAM/CGCGATCTCAACATCAGTCTGATAAGCTAGATCGC } \\
\text { GT/Dabcyl/TTTTTACGACACTACGTGGGAA }\end{array}$ \\
\hline $\begin{array}{l}\text { MB without Dabcyl } \\
\text { (MB-F) }\end{array}$ & $\begin{array}{l}\text { A/FAM/CGCGATCTCAACATCAGTCTGATAAGCTAGATCGC } \\
\text { GTTTTTTACGACACTACGTGGGAA }\end{array}$ \\
\hline $\begin{array}{l}\text { Label-free MB without } \\
\text { FAM and Dabcyl (MB-LF) }\end{array}$ & $\begin{array}{l}\text { ACGCGATCTCAACATCAGTCTGATAAGCTAGATCGCGTTT } \\
\text { TTTACGACACTACGTGGGAA }\end{array}$ \\
\hline $\begin{array}{l}\text { Molecular Beacon-7a } \\
\text { (MB-7a) }\end{array}$ & $\begin{array}{l}\text { A/FAM/CGCGATCAACTATACAACCTACTACCTCAGATCGC } \\
\text { GT/Dabcyl/TTTTTACGACACTACGTGGGAA }\end{array}$ \\
\hline Random Molecular & A/FAM/CGCGATCTGGTCTCAAGGCACCACCATGAGATCGC \\
\hline Beacon (rMB) & GT/Dabcyl/TTTTTACGACACTACGTGGGAA \\
\hline MB-6 & $\begin{array}{l}\text { GCGATCTCAACATCAGTCTGATAAGCTAGATCGCTTTTTA } \\
\text { CGACACTACGTGGGAA }\end{array}$ \\
\hline MB-10 & $\begin{array}{l}\text { CTACGCGATCTCAACATCAGTCTGATAAGCTAGATCGCGT } \\
\text { AGTTTTTACGACACTACGTGGGAA }\end{array}$ \\
\hline MB-12 & $\begin{array}{l}\text { AGCTACGCGATCTCAACATCAGTCTGATAAGCTAGATCGC } \\
\text { GTAGCTTTTTTACGACACTACGTGGGAA }\end{array}$ \\
\hline MB-8-1 & $\begin{array}{l}\text { AATATATCTCAACATCAGTCTGATAAGCTAGATATATTTT } \\
\text { TTTTACGACACTACGTGGGAA }\end{array}$ \\
\hline
\end{tabular}


MB-8-3

MB-8-7

Mismatch-1

Mismatch-2

Mismatch-3

Mismatch-4

Mismatch-5

MiR-21

DNA target-miR-21

(miR-21D)

DNA Target-Let-7a

(Let-7aD)

DNA target-Let 7d

(Let-7dD)

DNA target-miR-200b

(miR-200bD)

DNA target-miR-429

(miR-429D)

RT-miR-21

RT-U6

miR-21 forward

miR-21 reverse

U6 forward

U6 reverse

${ }^{\mathrm{a}} \mathrm{Cy} 5$ is attached to the 3 '-end for Sa-Cy5. Cy3 is attached to the $5^{\prime}$-end for Sb-Cy3. FAM (fluorophore carboxyfluorescein) is attached to the $3^{\prime}$-end for Sa-F. For MB and MB-7a, FAM is coupled to the $5^{\prime}$-end and Dabcyl is covalently positioned at the 38th italic base, $T$.
AATCGATCTCAACATCAGTCTGATAAGCTAGATCGATTTT

TTTTACGACACTACGTGGGAA

ACGCGGCCTCAACATCAGTCTGATAAGCTAGGCCGCGTTT

TTTTACGACACTACGTGGGAA

TATCTTATCAGACTGATGTTGA

TATATTATCAGACTGATGTTGA

TATATTATAAGACTGATGTTGA

TATATTATAATACTGATGTTGA

TATATTATTATAATGATGTTGA

UAGCUUAUCAGACUGAUGUUGA

TAGCTTATCAGACTGATGTTGA

TGAGGTAGTAGGTTGTATAGTT

AGAGGTAGTAGGTTGCATAGTT

TAATACTGCCTGGTAATGATGA

TAATACTGTCTGGTAAAACCGT

GTCGTATCCAGTGCAGGGTCCGAGGTATTCGCACTGGATAC

GACTCAACA

AACGCTTCACGAATTTGCGT

GCCGCTAGCTTATCAGACTGATGT

GTGCAGGGTCCGAGGT

CTCGCTTCGGCAGCACA

CTCGCITCGGCAGCACA

coupled to the 5 '-end and Dabcyl is covalently positioned at the 38 h italc base, $T$.

Table S2. Average Ct values in qRT-PCR assay of miR-21. ${ }^{\mathrm{a}}$

\begin{tabular}{cccccc}
\hline $\mathrm{E}_{2}$ & $\mathrm{miR}-21$ & $\mathrm{U} 6$ & $\Delta \mathrm{Ct}$ & $\Delta \Delta \mathrm{Ct}$ & $2^{-(\Delta \Delta \mathrm{Ct})}$ \\
\hline- & 22.23 & 16.76 & 5.47 & 0 & 1 \\
+ & 21.43 & 14.73 & 6.7 & 1.23 & 0.43 \\
\hline
\end{tabular}

${ }^{a}$ The value of $2^{-(\Delta \Delta \mathrm{Ct})}$ represents the relative expression level of miR-21. The data show that the expression level of miR-21 in MCF-7 treated with $\mathrm{E}_{2}$ is estimated to be 0.43 times that in untreated MCF-7 cell line, indicating that expression level of miR-21 is down-regulated in MCF-7 cell line after $\mathrm{E}_{2}$ treatment.

\section{Experimental procedure for qRT-PCR:}

Total cellular RNA was extracted from $\mathrm{E}_{2}$-treated MCF-7 cells and untreated MCF-7 cells, respectively, using TRIzol reagent. Then, the PrimeScript RT reagent Kit with gDNA Eraser was employed to remove the genomic DNA of total RNA and prepared the cDNA samples by using the reverse transcription (RT) reaction. The PCR amplification of miRNA was performed with TaKaRa Ex Taq HS in TB Green Premix Ex Taq Kit. The fluorescence intensity of TB Green in the reaction solution 
was used to detect the amplification of PCR products. The sequences used in this experiment are shown in Table S1. The real time PCR amplification and melt curves were obtained by CFX96 Time PCR Detection System. The $2^{-\Delta \Delta C t}$ method $^{1}$ was used to assess the relative expression level of miR-21.

Table S3. The limit of detection (LOD) of different methods for miRNA-21 detection.

\begin{tabular}{lccc}
\hline Detection method & LOD $(\mathrm{nM})$ & Cell targetability & Ref. \\
\hline Fluorescent biosensor & 0.33 & Unsuitable for the intracellular imaging & 2 \\
Plasmonic nanobiosensor & 3 & Unsuitable for the intracellular imaging & 3 \\
Particle-based suspension array & $1 \times 10^{-6}$ & Unsuitable for the intracellular imaging & 4 \\
Molecular beacon biosensor & 0.62 & No & 5 \\
Hairpin DNA cascade reaction & 0.5 & No & 6 \\
DNA tetrahedron-based nanosensor & 1 & No & 7 \\
Apt-Tri-MB & 0.1 & Yes & This work \\
\hline
\end{tabular}

\section{Discussion:}

For the DNA biosensors mentioned in Ref. 2, 3 and 4, non-nucleic acid materials were required. Moreover, the value of LOD reported in Ref. 2 and 3 is higher than the current work. Although the sensing array has the lower LOD, it is unsuitable for the imaging of intracellular miRNA.

In Ref. 5, DNA tetrahedron-mediated molecular beacon biosensor was proposed. Even if combining with 3D nanostructure, the value of LOD is higher than the current work.

In Ref. 6, a nonenzymatic hairpin DNA cascade reaction was proposed for the mRNA imaging inside live cells, but offering the unfavorable LOD $(0.5 \mathrm{nM})$ compared with the newly-developed Apt-Tri-MB. Moreover, transfection agents are needed for the imaging of intracellular miRNA.

In Ref. 7, a nature-inspired DNA nanosensor was proposed for the real-time in situ detection of mRNA in living cells. However, the LOD is only $1 \mathrm{nM}$, and the transfection agents are required to enable the cellular internalization of the nanosensor without the targetability. 
Table S4. The comparison of biological stability between several literature DNA nanostructures and our Tri-MB.

\begin{tabular}{lccc}
\hline Material & Tested conditions & Stability (h) & Ref. \\
\hline DNA triangle nanostructure & Nude mice & $<8 \mathrm{~h}$ & 8 \\
Cruciform DNA nanostructure & Fresh human serum & $7 \mathrm{~h}$ & 9 \\
DNA triangular prism nanomachine & $10 \%$ FBS & $6 \mathrm{~h}$ & 10 \\
DNA tetrahedron & Within cells & $48 \mathrm{~h}$ & 11 \\
Tri-MB & $10 \%$ FBS & $24 \mathrm{~h}$ & This work \\
\hline
\end{tabular}

\section{Discussion:}

In Ref. 8, a DNA nanotriangle-scaffolded activatable aptamer probe was constructed and its biological stability is less than $8 \mathrm{~h}$. Albeit having the similar spatial configuration (triangle), Tri-MB rigidified by $\mathrm{Y}$-shaped backbone shows the much higher stability.

Ref. 9 reports a cruciform DNA nanostructure with only 7-h FBS stability in fresh human serum that is much poorer than Tri-MB constructed in this work.

Ref. 10 describes a three-dimensional DNA triangular prism nanostructure. Compared with it, Tri-MB probe can keep intact for a significantly longer time.

Ref. 11 reports that three-dimensional DNA tetrahedron can remain intact for $48 \mathrm{~h}$, but no measured data demonstrate the residual amount and commercial transfection reagent was required to accomplish the cellular internalization. However, Tri-MB DNA probe displays the tumor target ability besides impressive stability. 
Table S5. The oligonucleotides used for the assembly of different DNA structures.

\begin{tabular}{|c|c|}
\hline DNA structure & Oligonucleotides used for assembly \\
\hline Tri-MB & $\mathrm{Sa}, \mathrm{Sb}, \mathrm{Sc}, \mathrm{Sd}, \mathrm{MB}$ \\
\hline Tri-MB-cy5 & $\mathrm{Sa}-\mathrm{Cy} 5, \mathrm{Sb}, \mathrm{Sc}, \mathrm{Sd}, \mathrm{MB}-\mathrm{LF}$ \\
\hline Lip-Tri-MB & $\mathrm{Sa}-\mathrm{Cy} 5, \mathrm{Sb}, \mathrm{Sc}, \mathrm{Sd}, \mathrm{MB}, \mathrm{Lip}-3000$ \\
\hline Apt-Tri-MB & $\mathrm{Sa}-\mathrm{Cy} 5, \mathrm{Sb}, \mathrm{Sc}-\mathrm{Apt}, \mathrm{Sd}, \mathrm{MB}$ \\
\hline rApt-Tri-MB & $\mathrm{Sa}-\mathrm{Cy} 5, \mathrm{Sb}, \mathrm{Sc}-\mathrm{rApt}, \mathrm{Sd}, \mathrm{MB}$ \\
\hline Apt-Tri-rMB & $\mathrm{Sa}-\mathrm{Cy} 5, \mathrm{Sb}, \mathrm{Sc}-\mathrm{Apt}, \mathrm{Sd}, \mathrm{rMB}$ \\
\hline Tri-MB-6 & $\mathrm{Sa}, \mathrm{Sb}, \mathrm{Sc}, \mathrm{Sd}, \mathrm{MB}-6$ \\
\hline Tri-MB-LF & $\mathrm{Sa}, \mathrm{Sb}, \mathrm{Sc}, \mathrm{Sd}, \mathrm{MB}-\mathrm{LF}$ \\
\hline Tri-MB-10 & $\mathrm{Sa}, \mathrm{Sb}, \mathrm{Sc}, \mathrm{Sd}, \mathrm{MB}-10$ \\
\hline Tri-MB-12 & $\mathrm{Sa}, \mathrm{Sb}, \mathrm{Sc}, \mathrm{Sd}, \mathrm{MB}-12$ \\
\hline Tri-MB-8-1 & $\mathrm{Sa}, \mathrm{Sb}, \mathrm{Sc}, \mathrm{Sd}, \mathrm{MB}-8-1$ \\
\hline Tri-MB-8-3 & $\mathrm{Sa}, \mathrm{Sb}, \mathrm{Sc}, \mathrm{Sd}, \mathrm{MB}-8-3$ \\
\hline Tri-MB-8-7 & $\mathrm{Sa}, \mathrm{Sb}, \mathrm{Sc}, \mathrm{Sd}, \mathrm{MB}-8-7$ \\
\hline Apt-Tri-MB-F & $\mathrm{Sa}, \mathrm{Sb}, \mathrm{Sc}-\mathrm{Apt}, \mathrm{Sd}, \mathrm{MB}-\mathrm{F}$ \\
\hline Apt-Tri-MB-Сy5 & Sa-Cy5, Sb, Sc-Apt, Sd, MB-LF \\
\hline Apt-Tri-MB-Cy3 & $\mathrm{Sa}, \mathrm{Sb}-\mathrm{Cy} 3, \mathrm{Sc}-\mathrm{Apt}, \mathrm{Sd}, \mathrm{MB}-\mathrm{LF}$ \\
\hline Apt-Tri-MB-FRET & Sa-Cy5, Sb-Cy3, Sc-Apt, Sd, MB-LF \\
\hline Apt-MB-F & Apt, MB-F \\
\hline Apt-Tri-MB-7a & $\mathrm{Sa}, \mathrm{Sb}, \mathrm{Sc}-\mathrm{Apt}, \mathrm{Sd}, \mathrm{MB}-7 \mathrm{a}$ \\
\hline Qua-MB & $\mathrm{Sa}, \mathrm{Sb}, \mathrm{Se}, \mathrm{Sf}, \mathrm{Sg}, \mathrm{MB}$ \\
\hline Qua-MB-Cy5 & $\mathrm{Sa}-\mathrm{Cy} 5, \mathrm{Sb}, \mathrm{Se}, \mathrm{Sf}, \mathrm{Sg}, \mathrm{MB}-\mathrm{LF}$ \\
\hline Apt-Qua-MB & $\mathrm{Sa}-\mathrm{Cy} 5, \mathrm{Sb}, \mathrm{Se}, \mathrm{Sf}, \mathrm{Sg}-\mathrm{Apt}, \mathrm{MB}$ \\
\hline Apt-Qua-MB-F & $\mathrm{Sa}, \mathrm{Sb}, \mathrm{Se}, \mathrm{Sf}, \mathrm{Sg}-\mathrm{Apt}, \mathrm{MB}-\mathrm{F}$ \\
\hline Apt-Qua-MB-Cy5 & $\mathrm{Sa}-\mathrm{Cy} 5, \mathrm{Sb}, \mathrm{Se}, \mathrm{Sf}, \mathrm{Sg}-\mathrm{Apt}, \mathrm{MB}-\mathrm{LF}$ \\
\hline Apt-Qua-MB-Cy3 & $\mathrm{Sa}, \mathrm{Sb}-\mathrm{Cy} 3, \mathrm{Se}, \mathrm{Sf}, \mathrm{Sg}-\mathrm{Apt}, \mathrm{MB}-\mathrm{LF}$ \\
\hline Apt-Qua-MB-FRET & Sa-Cy5, Sb-Cy3, Se, Sf, Sg-Apt, MB-LF \\
\hline Tri-1 + MB & $\mathrm{Sa}, \mathrm{Sb}, \mathrm{Sc}, \mathrm{Sf}, \mathrm{MB}-\mathrm{F}$ \\
\hline
\end{tabular}




\section{Supplementary Figures}

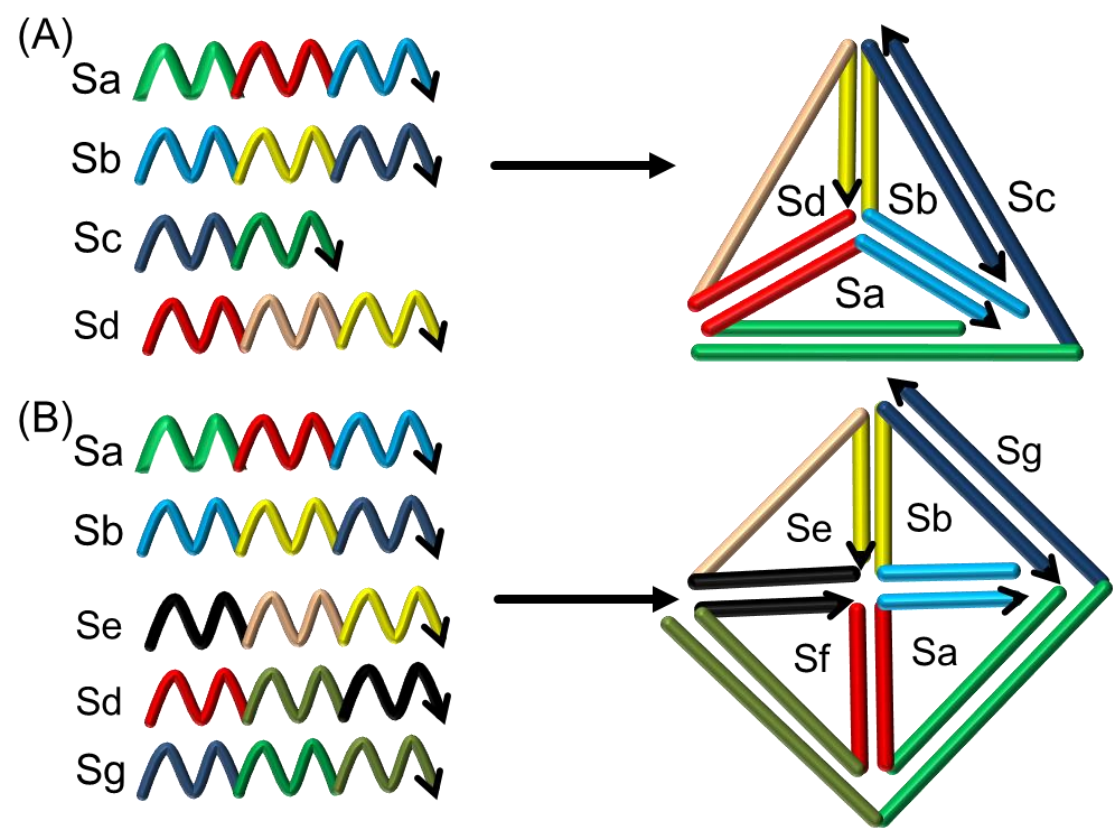

Scheme S1. (A) Schematic illustration of DNA triangle rigidified by a Y-shaped backbone. The single-stranded DNA side of triangle is available for the further hybridization-based functionalization, and it is easy to extend the Sc from its termini when needed. (B) Schematic illustration of DNA quadrangle rigidified by a X-shaped backbone. 


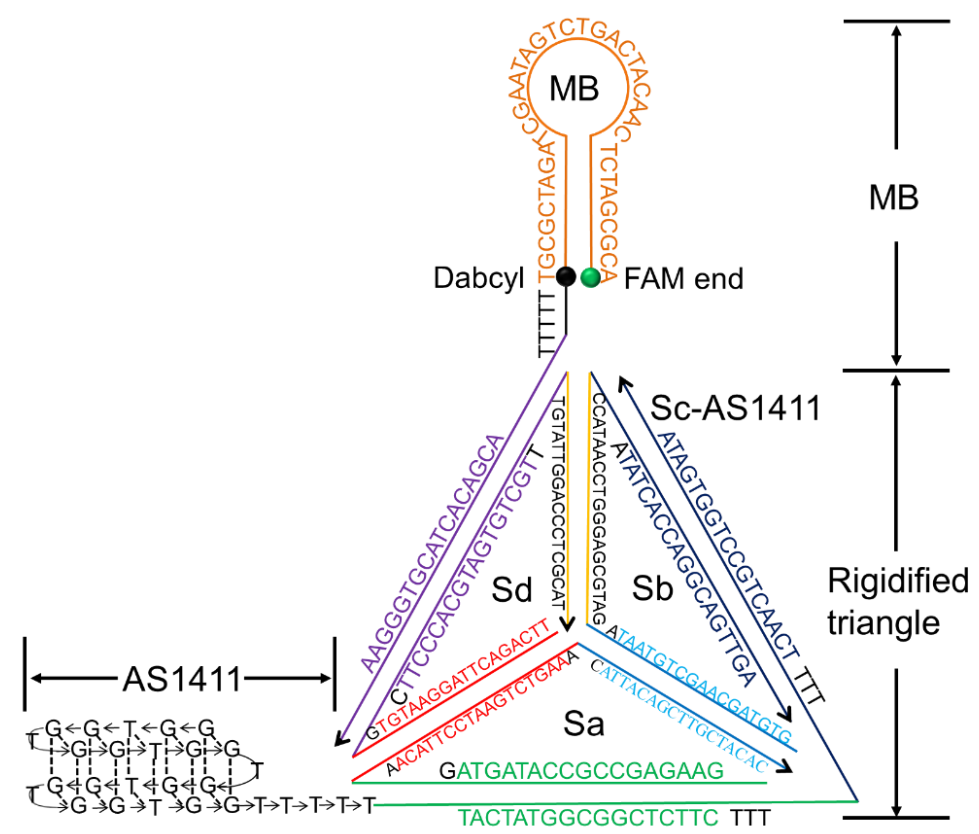

Scheme S2. The structural representation of Apt-Tri-MB including the functional domains, the base sequences of DNA components and the position of targeting aptamer, FAM end and Dabcyl. 


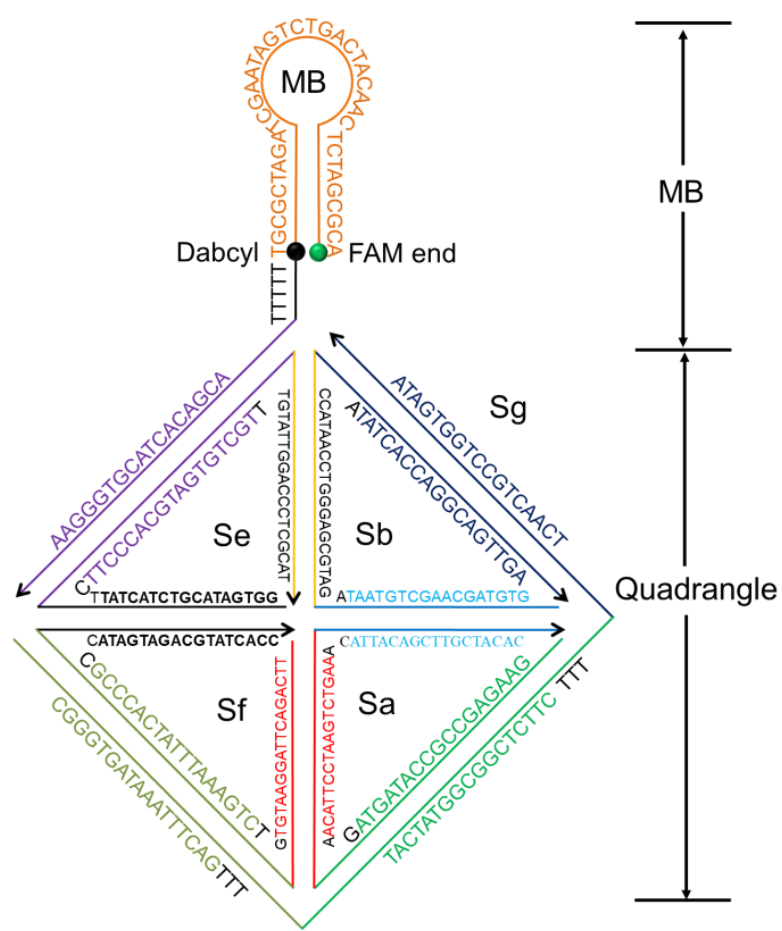

Scheme S3. The structural representation of Qua-MB consisting of $x$-shaped backbone-rigidified DNA quadrangle and signaling MB. 


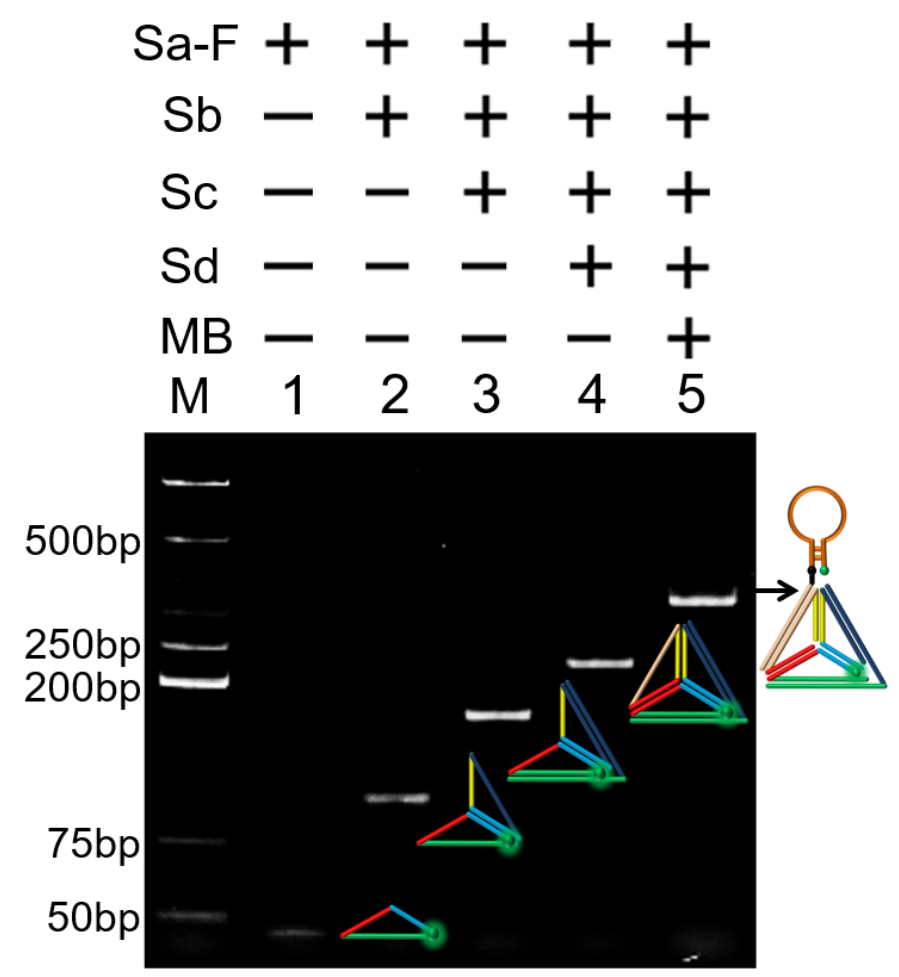

Figure S1. The stepwise assembly of Tri-MB characterized by $6 \%$ nPAGE. Lane M: Marker; Lane 1: Sa-F; Lane 2: Sa-F + Sb; Lane 3: Sa-F + Sb + Sc; Lane 4: Sa-F + Sb $+\mathrm{Sc}+\mathrm{Sd}$; Lane 5: Sa-F $+\mathrm{Sb}+\mathrm{Sc}+\mathrm{Sd}+\mathrm{MB}$.

\section{Experimental procedure:}

The stepwise assembly of Tri-MB was characterized as described in the section of 'Gel electrophoresis'. 

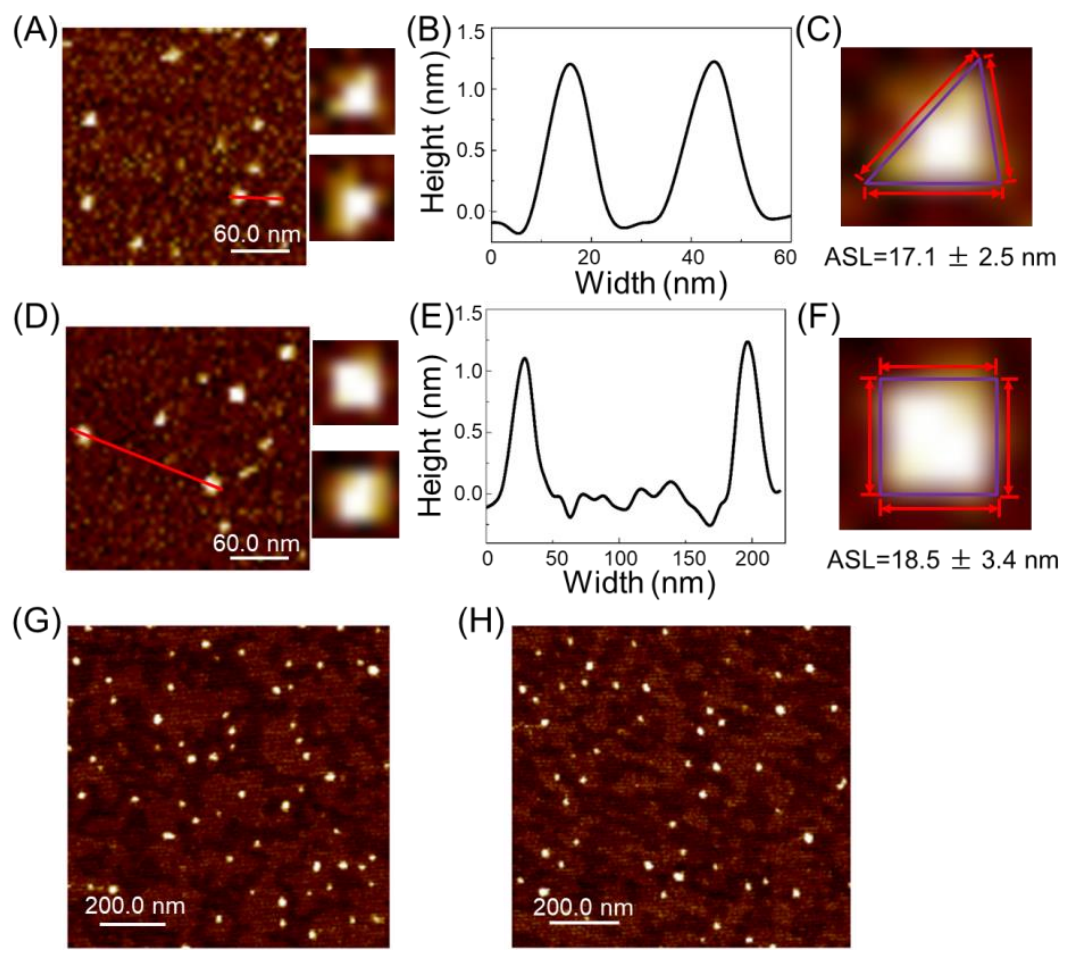

Figure S2. AFM characterization of Tri-MB and Qua-MB. (A) AFM image of Tri-MB. The right panel shows the enlarged images. (B) The height profile along the red line in (A). (C) The length analysis of triangle sides. (D), (E) and (F) are the same as $(A),(B)$ and $(C)$, respectively, but Qua-MB is instead characterized. $(\mathrm{G})$ and $(\mathrm{H})$ are the wide field AFM image of Tri-MB and Qua-MB, respectively.

\section{Discussion:}

As shown in AFM images (Figure S2 A to F), the triangular geometry of Tri-MB and quadrangular geometry of Qua-MB are roughly observed. The height of two DNA nanoassemblies is $\sim 1.3 \mathrm{~nm}$, which is consistent with the literature value. ${ }^{12}$ The average side lengths (ASL) of Tri-MB and Qua-MB are $17.1 \pm 2.5 \mathrm{~nm}$ and $18.5 \pm 3.4$ $\mathrm{nm}$, respectively. The theoretical value of ASL is $5.8 \mathrm{~nm}$ because the number of base pairs of each side of two assembled nanobricks is 17 base pairs and the distance between adjacent base pairs is $0.34 \mathrm{~nm}$. The difference in ASL between the measured value and theoretically-calculated value should be attributed to the well-known tip-broadening effect. ${ }^{12-14}$ In addition, the mean size (MS) of Tri-MB is $17.2 \pm 2.2 \mathrm{~nm}$ $(n=50)$ and the Qua-MB MS is $18.6 \pm 3.6 \mathrm{~nm}(\mathrm{n}=40)$, which were estimated from the wide field AFM images (Figure S2 G and F).

\section{Experimental procedure:}

Tri-MB assembly: the details are seen in Figure S1.

Qua-MB assembly: The Qua-MB was assembled from six DNA strands, $\mathrm{Sa}, \mathrm{Sb}, \mathrm{Se}, \mathrm{Sf}$, $\mathrm{Sg}$ and $\mathrm{MB}$ at a molar ratio of 1:1:1:1:1:1. Specifically, five DNA strands ( $\mathrm{Sa}, \mathrm{Sb}, \mathrm{Se}$, Sf and Sg, each $1 \mu \mathrm{L}, 10 \mu \mathrm{M})$ were added into $1 \times \mathrm{TE}$ buffer $(19 \mu \mathrm{L})$, followed by 
annealing at $90{ }^{\circ} \mathrm{C}$ for $5 \mathrm{~min}$ and gradually cooling to room temperature. Then, the resulting solution was mixed with $\mathrm{MB}$ strand $(1 \mu \mathrm{L}, 10 \mu \mathrm{M})$ and incubated at $37{ }^{\circ} \mathrm{C}$ for $2 \mathrm{~h}$, forming the Qua-MB probes (the final concentration, $0.4 \mu \mathrm{M}$ ).

AFM measurement: the ready-prepared Tri-MB $(10 \mu \mathrm{L}, 0.4 \mu \mathrm{M})$ or Qua-MB $(10 \mu \mathrm{L}$, $0.4 \mu \mathrm{M}$ ) was deposited onto the freshly-cleaved mica surface for $30 \mathrm{~min}$. Then, the mica surface was washed by $\mathrm{ddH}_{2} \mathrm{O}$ and dried with nitrogen for image. AFM imaging was performed on a MultiMode 8 atomic force microscope (Bruker, Germany) with ScanAsyst Mode.
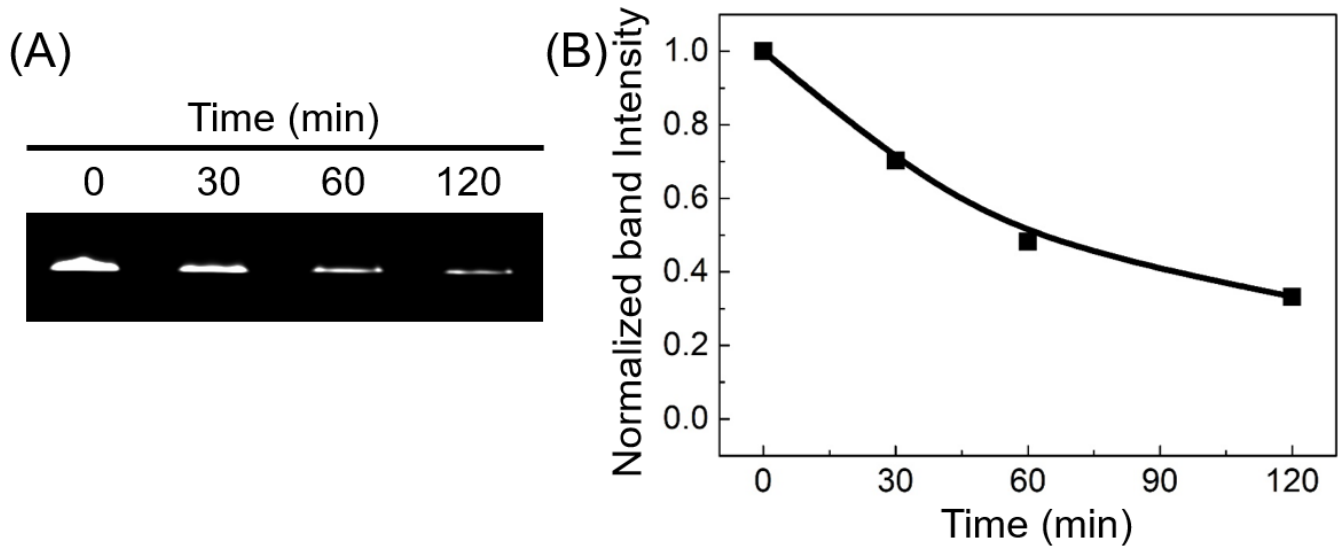

Figure S3. The nuclease stability of Qua-MB. (A) The dPAGE analysis of Qua-MB treated with $2 \mathrm{U} / \mathrm{ml}$ DNase I, where probes always were in the ON state because MB-F without the quencher was employed instead of MB. (B) The fluorescent quantitative fluorescence measurement of gel images (A) processed by Image Lab software.

\section{Experimental procedure:}

The Qua-MB was assembled as described in Figure S2. The resulting Qua-MB $(25 \mu \mathrm{L}$, $0.4 \mu \mathrm{M})$ was incubated with DNase $\mathrm{I}(2 \mathrm{U} / \mathrm{mL})$ at $37^{\circ} \mathrm{C}$ for $0,30,60$ or $120 \mathrm{~min}$. Afterwards, the resulting solution was heated to $75^{\circ} \mathrm{C}$ for $10 \mathrm{~min}$ to terminate the enzymatic digestion. The products were analyzed by denatured polyacrylamide gel electrophoresis (dPAGE, 10\%) in $0.5 \times$ TBE buffer at $30 \mathrm{~mA}$ for $20 \mathrm{~min}$. The loading sample was prepared via mixing $10 \mu \mathrm{L}$ of reaction solution with $10 \mu \mathrm{L}$ of $2 \times$ loading buffer. 

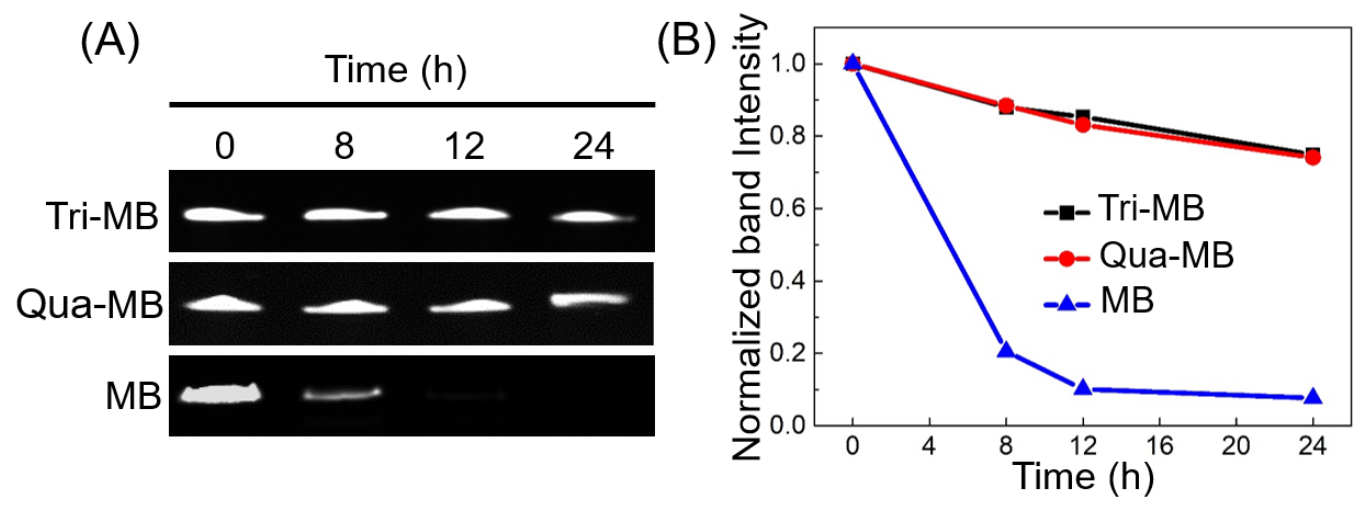

Figure S4. The biological stability of Tri-MB and Qua-MB. (A) The dPAGE analysis of Tri-MB, Qua-MB and MB treated with $10 \%$ FBS. All the probes always are in the ON state because MB-F without the quencher was employed instead of MB. (B) The quantitative fluorescence measurement of gel images (A) processed by Image Lab software.

\section{Experimental procedure:}

The Tri-MB $(25 \mu \mathrm{L}, 0.4 \mu \mathrm{M})$, Qua-MB $(25 \mu \mathrm{L}, 0.4 \mu \mathrm{M})$ and $\mathrm{MB}(25 \mu \mathrm{L}, 0.4 \mu \mathrm{M})$ were separately incubated with $10 \% \mathrm{FBS}$ at $37^{\circ} \mathrm{C}$ for $0,8,12$ or $24 \mathrm{~h}$. Afterwards, the resulting solution was heated at $75^{\circ} \mathrm{C}$ for $10 \mathrm{~min}$ to terminate the enzymatic digestion. The products were analyzed by $10 \%$ dPAGE in $0.5 \times$ TBE buffer at $30 \mathrm{~mA}$ for $20 \mathrm{~min}$. The loading sample was prepared by mixing $10 \mu \mathrm{L}$ of reaction solution with $10 \mu \mathrm{L}$ of $2 \times$ loading buffer. 

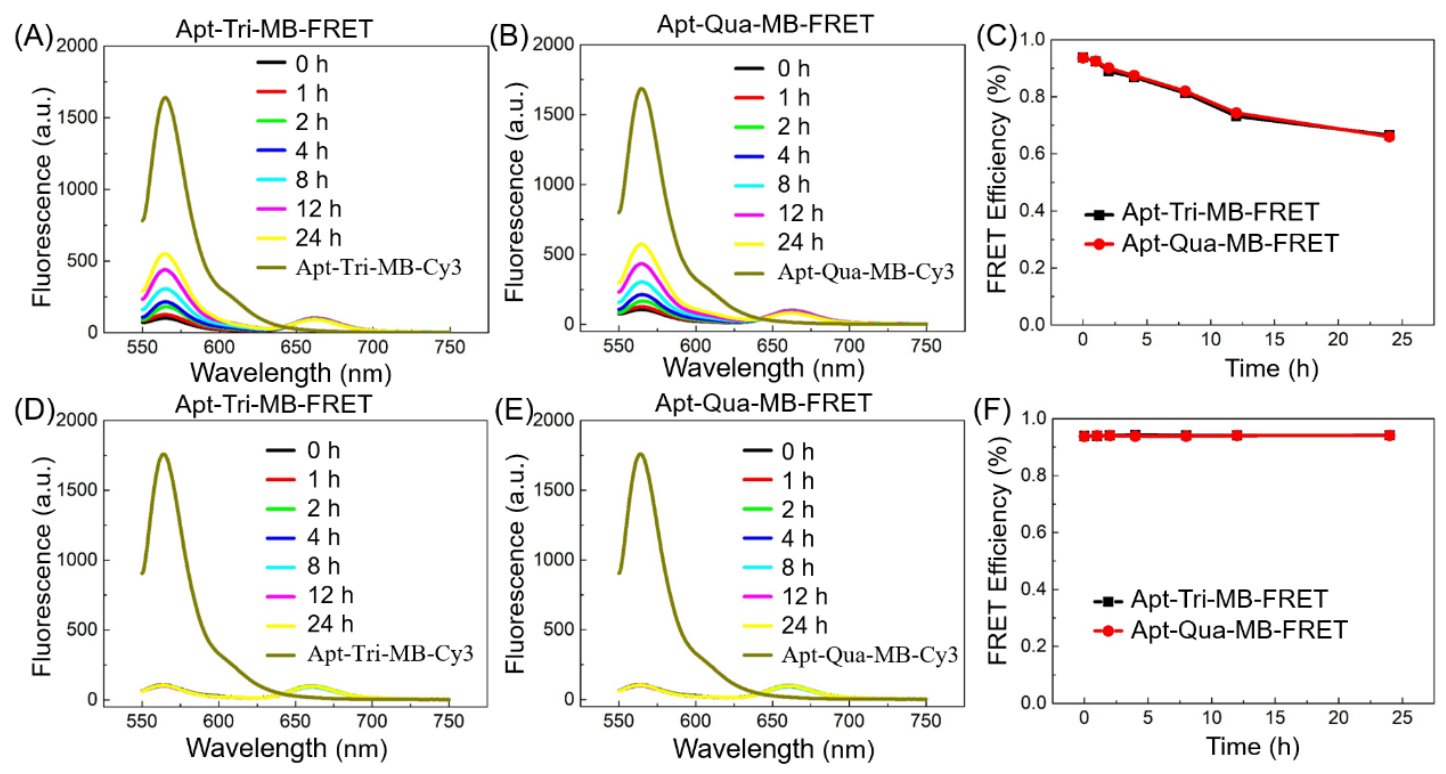

Figure S5. Fluorescence spectra of Apt-Tri-MB-FRET (A) and Apt-Qua-MB-FRET (B) incubated in $10 \%$ FBS at $37^{\circ} \mathrm{C}$ for $0,1,2,4,8,12$ or $24 \mathrm{~h}$. Apt-Tri-MB-Cy3 and Apt-Qua-MB-Cy3 were used as controls, whose fluorescence emission is from Cy3. (C) FRET efficiency of Apt-Tri-MB-FRET and Apt-Qua-MB-FRET is estimated from panels A and B. (D), (E) and (F) are the same as (A), (B) and (C), respectively, but $1 \times$ TE buffer was used instead of $10 \%$ FBS.

\section{Experimental procedure:}

The Apt-Tri-MB-FRET (or Apt-Qua-MB-FRET) (final concentration, $0.4 \mu \mathrm{M}$ ) was incubated in $10 \%$ FBS (or $1 \times \mathrm{TE}$ buffer) (final volume, $25 \mu \mathrm{L}$ ) at $37^{\circ} \mathrm{C}$ for $0,1,2,4$, 8,12 or $24 \mathrm{~h}$. Then, the volume of resulting solution was adjusted to $200 \mu \mathrm{L}$ by adding $1 \times \mathrm{TE}$ buffer. The fluorescence spectrum was collected at the excitation wavelength of $535 \mathrm{~nm}$ ( $\mathrm{slit}=5 \mathrm{~nm}$ ), while the emission wavelength range is from 550 to $750 \mathrm{~nm}$ (slits=5 nm) and the scanning speed is $240 \mathrm{~nm} / \mathrm{min}$. As the control, the fluorescence spectra of Apt-Tri-MB-Cy3 (or Apt-Qua-MB-Cy3) in 1×TE buffer were collected under identical conditions. The FRET efficiency (E) was calculated by the equation (1) ${ }^{15}$, where $\mathrm{F}_{\mathrm{DA}}$ is the donor (Cy3) fluorescence with acceptor (Cy5) and $\mathrm{F}_{\mathrm{D}}$ is the donor (Cy3) fluorescence without acceptor (Cy5).

$$
\mathrm{E}=1-\mathrm{F}_{\mathrm{DA}} / \mathrm{F}_{\mathrm{D}}
$$

\section{Discussion:}

As shown in Figure S5A and S5B, the Cy3 fluorescence of Apt-Tri-MB-FRET (or Apt-Qua-MB-FRET) exposed to FBS increases with the increment of incubating time. Figure S5C shows the quantitative analysis of FRET efficiency. The maximum FRET efficiency ( $0 \mathrm{~h}$ ) of Apt-Tri-MB-FRET and Apt-Qua-MB-FRET probes was about 94\%. After 24-h incubating, the FRET efficiency of Apt-Tri-MB-FRET and Apt-Qua-MB-FRET remains about $66 \%$. These results indicate that $70 \%$ of probes 
remain intact, which is consistent with the results of Figure S4. As demonstrated in Figure S5D, S5E and S5F, there is no detectable change in the FRET efficiency of Apt-Tri-MB-FRET and Apt-Qua-MB-FRET probes even after 24-h incubation in $1 \times$ TE buffer.
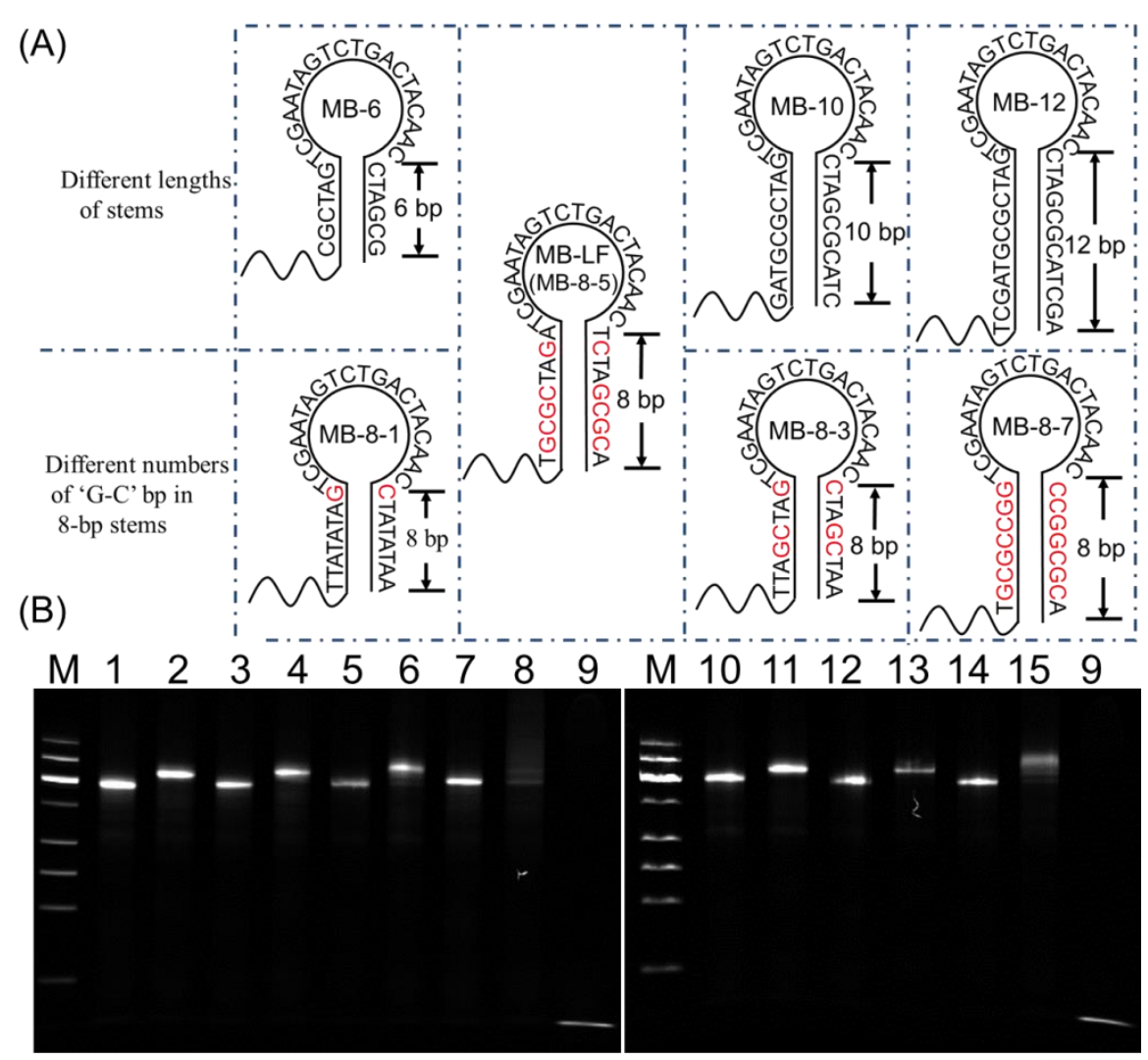

(C)

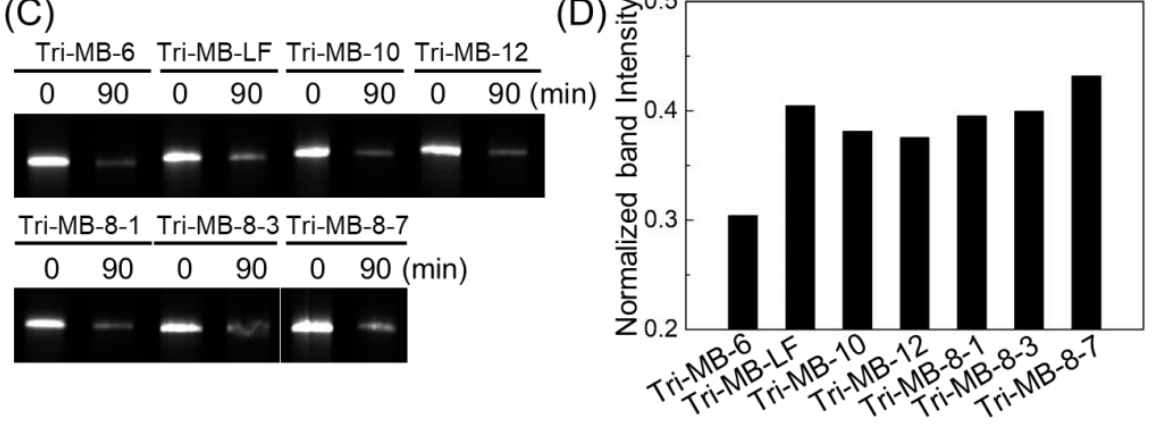

Figure S6. The optimization of nature and length of base-pairing-based stem of MB. (A) The schematic illustration of different MBs. (B) The ability of different types of Tri-MB to bind to target miRNA, which is characterized by $6 \%$ nPAGE. Lane M: Marker; Lane 1: Tri-MB-6; Lane 2: Tri-MB-6 + miR-21D; Lane 3: Tri-MB-LF; Lane 4: Tri-MB-LF + miR-21D; Lane 5: Tri-MB-10; Lane 6: Tri-MB-10 + miR-21D; Lane 7: Tri-MB-12; Lane 8: Tri-MB-12 + miR-21D; Lane 9: miR-21D; Lane 10: Tri-MB-8-1; Lane 11: Tri-MB-8-1 + miR-21D; Lane 12: Tri-MB-8-3; Lane 13: Tri-MB-8-3 + miR-21D; Lane 14: Tri-MB-8-7; Lane 15: Tri-MB-8-7 + miR-21D. (C) 
The 6\% nPAGE analysis of different types of Tri-MB treated with $2 \mathrm{U} / \mathrm{ml}$ DNase I at $37{ }^{\circ} \mathrm{C}$ for $90 \mathrm{~min}$. (D) The quantitative fluorescence measurement of gel images (C) processed by Image Lab software. The normalized band intensity was the value of $\mathrm{F}_{90} / \mathrm{F}_{0}$, where $\mathrm{F}_{90}$ and $\mathrm{F}_{0}$ indicate the band intensity at $90 \mathrm{~min}$ and $0 \mathrm{~min}$, respectively.

\section{Discussion:}

The number and nature of base pairs in the stem of MB may affect the binding of target or nuclease degradation. Thus, before detecting the target miRNA, the number and nature of base pairs of MB's stem were optimized to improve the ability to identify target molecules and to resist enzymatic degradation. The schematic illustration of different types of MBs is shown in Figure S6A. Firstly, MBs with the different lengths of stems, including MB-6, MB-LF, MB-10 and MB-12 respectively with $6,8,10$ and 12 base pairs, were explored. The ability of different Tri-MBs to hybridize with target species was evaluated by $6 \%$ nPAGE analysis (Figure S6B). As shown in Figure S6B, most of Tri-MB probes can efficiently hybridize with miR-21D, but the bands of Tri-MB-12/miR-21D and Tri-MB-8-7/miR-21D are relatively weaker. Of note, considering that MB-LF (seen in the left part) has 5 "G-C" base pairs in the stem (also called MB-8-5), other MBs with different types of 8 base pairs, MB-8-1, MB-8-3 and MB-8-7, were designed to have 1, 3 and 7 "G-C" base pairs, respectively. Their target hybridization capability is shown in the right part. Moreover, we examined the anti-degradation ability of different Tri-MB probes by $6 \%$ nPAGE and the results are shown in Figure S6C. Meanwhile, the residual DNA bands were quantified by Image Lab software. As described in Figure S6D, one can find that the residual amount of Tri-MB-LF and Tri-MB-8-7 are slightly higher than other probes. Because Tri-MB-8-7 shows a relatively weak binding ability with target, we chose the Tri-MB-LF as the detection probes in this study.

\section{Experimental procedure:}

The ability of Tri-MB with to bind to target: Tri-MB-6, Tri-MB-LF, Tri-MB-10, Tri-MB-12, Tri-MB-8-1, Tri-MB-8-3 and Tri-MB-8-7 were prepared according to the same procedure as that for construction of Tri-MB. But, the MB was substituted with MB-6, MB-LF, MB-10, MB-12, MB-8-1, MB-8-3 and MB-8-7. Then, the different type probes $(25 \mu \mathrm{L}, 0.4 \mu \mathrm{M})$ were incubated with miR-21D $(1 \mu \mathrm{L}, 10 \mu \mathrm{M})$ at $37{ }^{\circ} \mathrm{C}$ for $2 \mathrm{~h}$. Subsequently, the resulting products were analyzed by $6 \%$ nPAGE in $0.5 \times$ TBE buffer at $60 \mathrm{~V}$ for $60 \mathrm{~min}$. The loading sample was prepared via mixing $8 \mu \mathrm{L}$ of reaction solution with $2 \mu \mathrm{L}$ of $6 \times$ loading buffer and $2 \mu \mathrm{L}$ of $10 \times$ Sybr green.

Exploration of biological stability: Tri-MB $(25 \mu \mathrm{L}, 0.4 \mu \mathrm{M})$ was incubated with 2 $\mathrm{U} / \mathrm{mL}$ DNase I at $37{ }^{\circ} \mathrm{C}$ for $0,90 \mathrm{~min}$. Then, the degradation products were analyzed by $6 \% \mathrm{nPAGE}$ in $0.5 \times \mathrm{TBE}$ buffer at $60 \mathrm{~V}$ for $60 \mathrm{~min}$. The loading sample was prepared via mixing $8 \mu \mathrm{L}$ of reaction solution with $2 \mu \mathrm{L}$ of $6 \times$ loading buffer and $2 \mu \mathrm{L}$ of $10 \times$ Sybr green. 

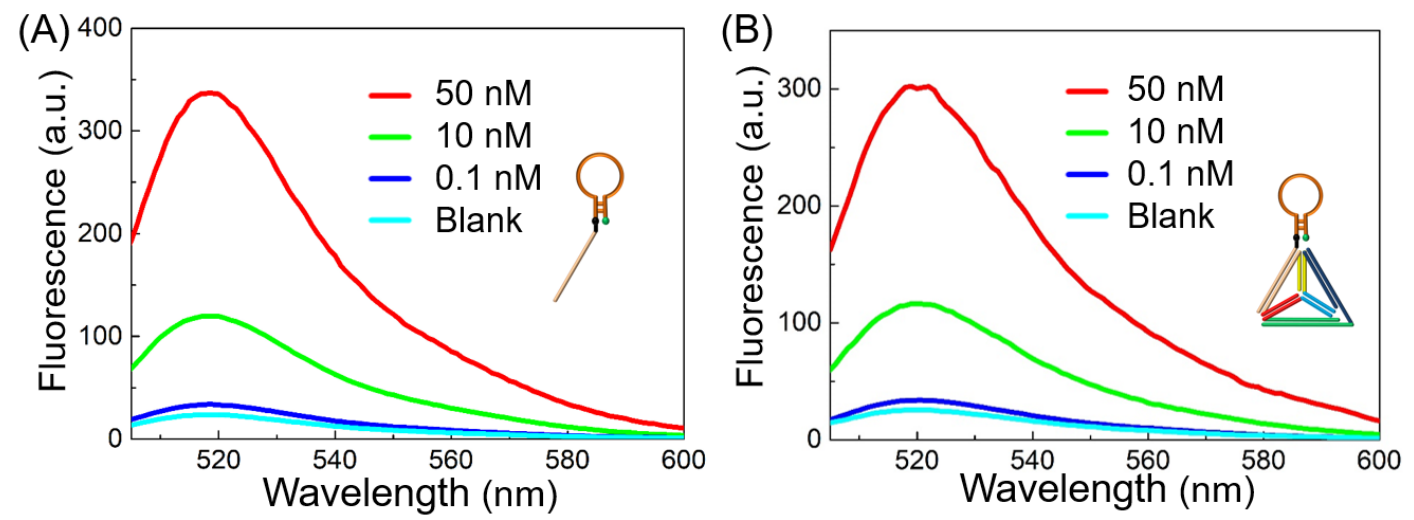

Figure S7. (A) Fluorescence spectra of $M B$ after incubation with different concentrations of miR-21D for $2 \mathrm{~h}$. For the Blank, $1 \times$ TE buffer was used instead of miR-21D. (B) Fluorescence spectra of Tri-MB after incubation with different concentrations of miR-21 for $2 \mathrm{~h}$. For the Blank, $1 \times \mathrm{TE}$ buffer was used instead of miR-21.

\section{Experimental procedure:}

Panel (A): To access the detecting sensitivity of MB alone, MB $(25 \mu \mathrm{L}, 0.4 \mu \mathrm{M})$ was incubation with variable concentrations of DNA target (final concentration: $0.1 \mathrm{nM}$, $10 \mathrm{nM}, 50 \mathrm{nM}$ ) or the same volume of $1 \times \mathrm{TE}$ buffer (Blank). Then, total volume was adjusted to $200 \mu \mathrm{L}$ with $1 \times \mathrm{TE}$ buffer. After the 2 -h incubation at $37{ }^{\circ} \mathrm{C}$, the fluorescence spectrum of resulting solution was collected. The hybridization and fluorescence measurement were performed under experimental conditions identical to those adopted for Tri-MB system.

Panel (B): Compared with panel (A), the miR-21 was used instead of miR-21D, and the assay experiment was performed according to the same procedure. 

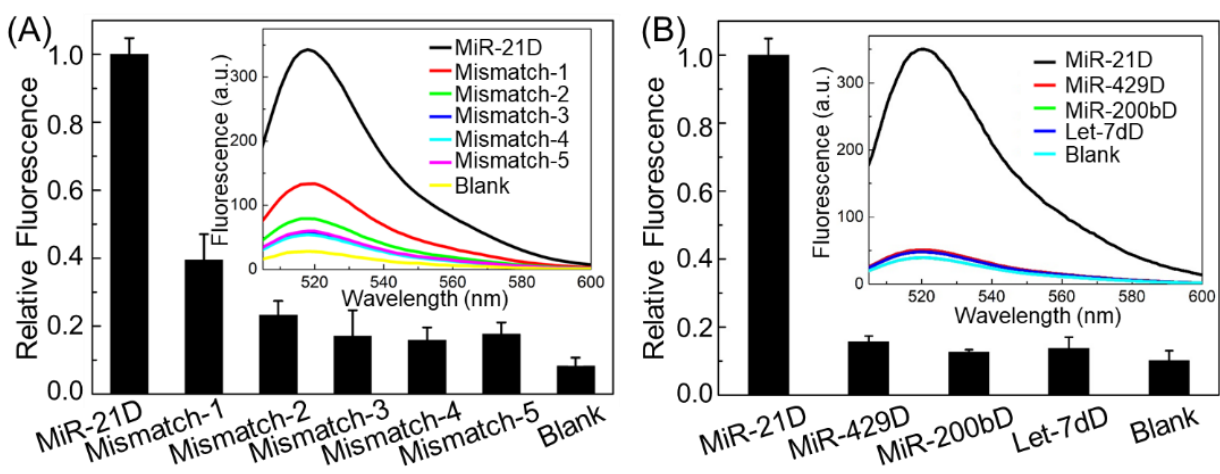

Figure S8. The specificity of Tri-MB towards the target sequence. (A) Relative fluorescence intensity of Tri-MB upon the perfectly complementary target (corresponding fluorescence signal is defined as 1) and mutant targets. Inset: the corresponding fluorescence spectra of Tri-MB system upon these targets. (B) Relative fluorescence intensity of Tri-MB to evaluate the specificity against several DNA species, miRNA target analogues. Inset: the fluorescence spectra of corresponding Tri-MB system upon these species. Blank indicates that the target was substituted by the corresponding buffer. Error bars are obtained from three independent parallel experiments.

\section{Experimental procedure:}

Tri-MB (25 $\mu \mathrm{L}, 0.4 \mu \mathrm{M}$, adjusted to $199 \mu \mathrm{L}$ with $1 \times \mathrm{TE}$ buffer $)$ solutions were separately incubated with DNA simulants of miRNA $(1 \mu \mathrm{L}, 10 \mu \mathrm{M})$, mutant target DNA $(1 \mu \mathrm{L} 10 \mu \mathrm{M})$, analogue of miRNA-21 and its family members $(1 \mu \mathrm{L}, 10 \mu \mathrm{M})$ at $37{ }^{\circ} \mathrm{C}$ for $2 \mathrm{~h}$. Then, the fluorescence spectra of resulting solutions were recorded as described in the section of 'Fluorescence detection'. 


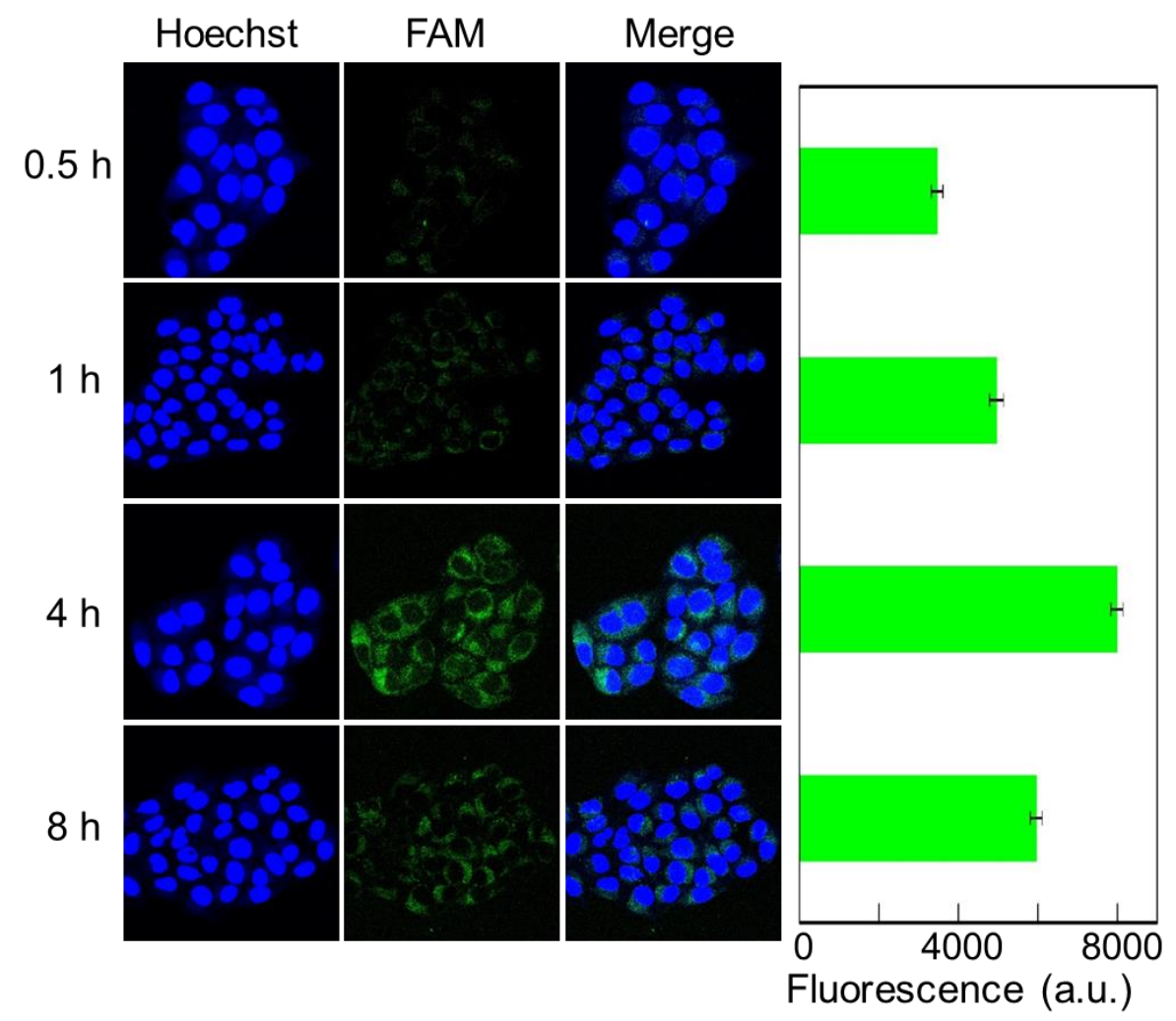

Figure S9. Confocal fluorescence imaging of miR-21 within MCF-7 cells treated with Apt-Tri-MB at different incubation times. The right panel: the corresponding quantitative fluorescence measurement. The green florescence emits from FAM attached to MB. Error bars are obtained from three independent parallel experiments.

\section{Experimental procedure:}

The MCF-7 cells were incubated with Apt-Tri-MB (the final concentration: $50 \mathrm{nM}$ ) for $0.5,1,4$ or $8 \mathrm{~h}$. After washing by normal saline, to perform nuclear staining, the cells were incubated with $1 \mu \mathrm{M}$ Hoechst 33342 for $10 \mathrm{~min}$. The resulting cells were washed with normal saline before imaging. Confocal imaging experiments were performed on laser scanning confocal microscope (Leica TCS SP8, Germany). 


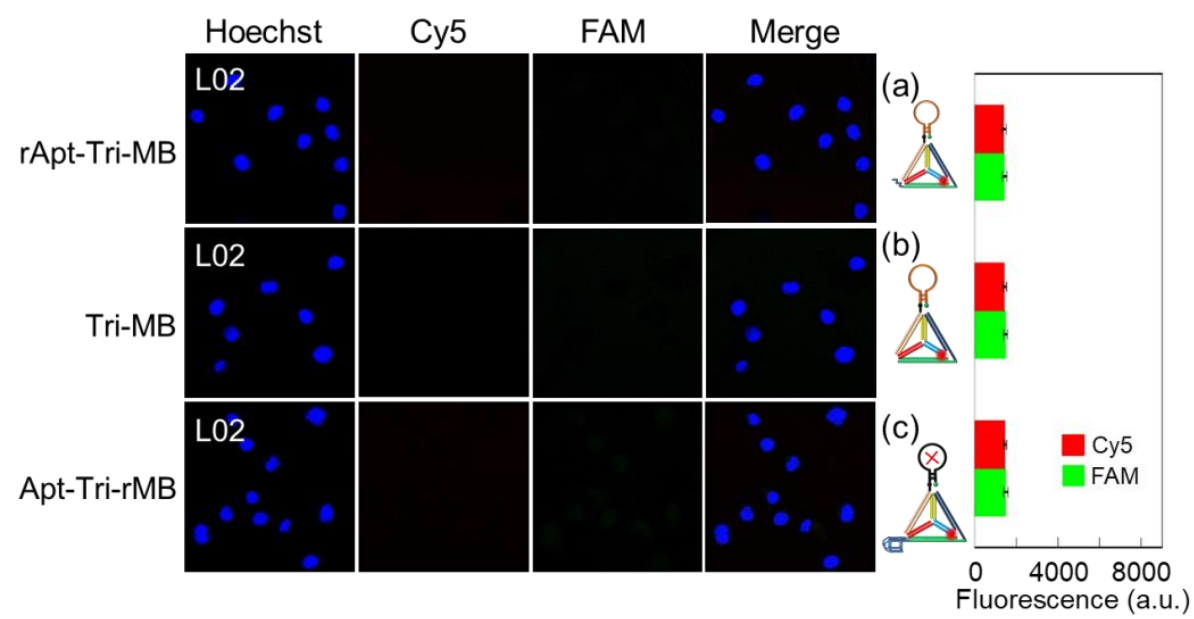

Figure S10. Confocal fluorescence images of L02 cells treated by rApt-Tri-MB (a), Tri-MB (b) or Apt-Tri-rMB (c). The right panel shows the corresponding quantitative fluorescence intensity. Error bar is obtained from three independent parallel experiments.

\section{Experimental procedure:}

L02 cells were incubated with rApt-Tri-MB, Tri-MB or Apt-Tri-rMB (final concentration, $50 \mathrm{nM}$ ) for $4 \mathrm{~h}$. After washing by normal saline, the cells were incubated with $1 \mu \mathrm{M}$ Hoechst 33342 for $10 \mathrm{~min}$ to execute nuclear staining, followed by washing with normal saline again. Confocal imaging experiments were performed on laser scanning confocal microscope (Leica TCS SP8, Germany). 


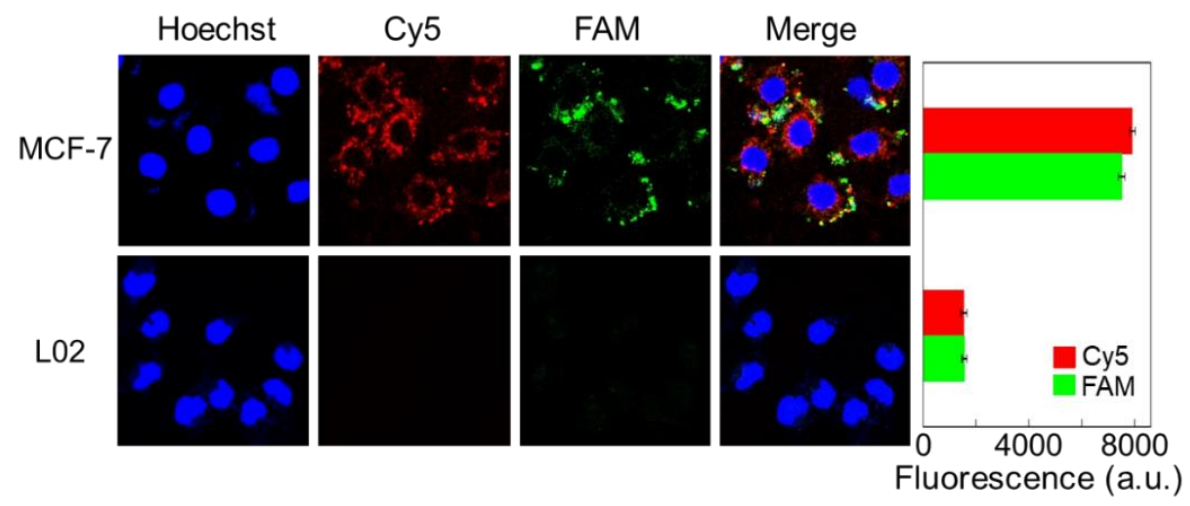

Figure S11. Confocal fluorescence images of miR-21 inside MCF-7 and L02 cells treated by Apt-Qua-MB. The right panel shows the corresponding quantitative fluorescence intensity. Error bar is obtained from three independent parallel experiments.

\section{Experimental procedure:}

To study the tumor-targeting ability of Apt-Qua-MB, MCF-7 cells and L02 cells were separately incubated with Apt-Qua-MB (final concentration, $50 \mathrm{nM}$ ) for $4 \mathrm{~h}$. After washing by normal saline, the cells were incubated with $1 \mu \mathrm{M}$ Hoechst 33342 for 10 min to execute nuclear staining, followed by washing with normal saline again. Confocal imaging experiments were performed on laser scanning confocal microscope (Leica TCS SP8, Germany).

\section{Discussion:}

We also examined the feasibility of Apt-Qua-MB for imaging intramolecular miRNAs. As shown in Figure S11, the strong red fluorescence of Cy5 and strong green fluorescence of FAM are detected in MCF-7 cells, indicating the cellular internalization of Apt-Qua-MB and the hybridization between MB and miRNA-21. In contrast, L02 cells treated under identical conditions do not exhibit any obvious fluorescence signal. These measured data demonstrates that Apt-Qua-MB can be used to distinguish the cancerous cells from healthy cells by specifically internalizing into MCF-7 cells and sensing the intracellular miR-21. 


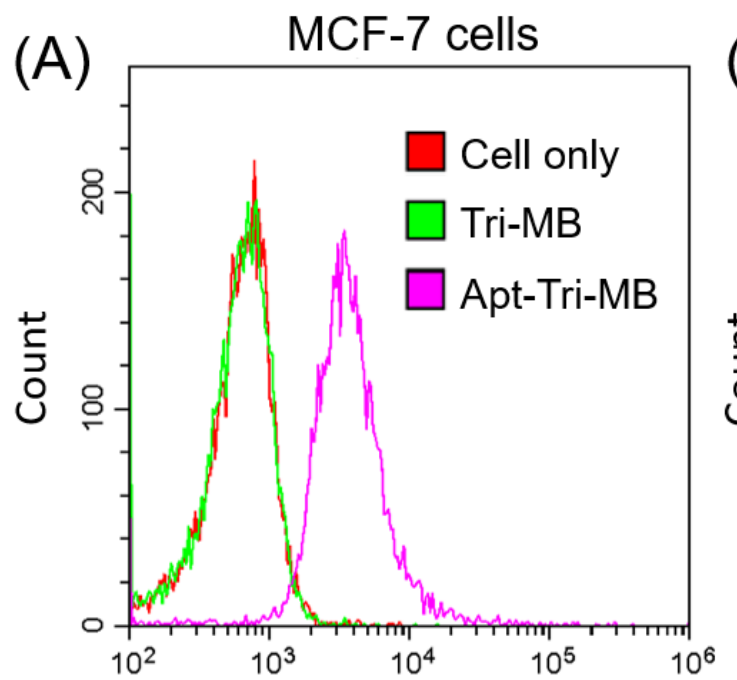

(C)

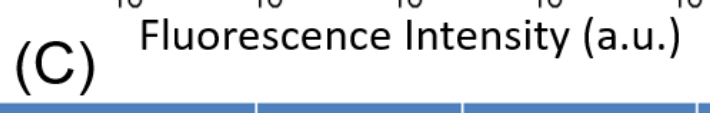

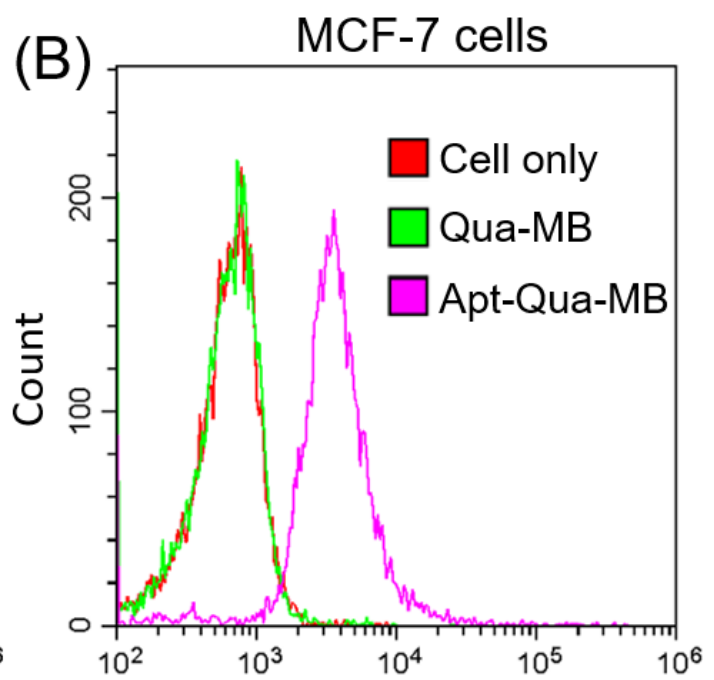

Fluorescence Intensity (a.u.)

\begin{tabular}{|c|c|c|c|c|c|}
\hline Sample & Cell only & Tri-MB & Apt-Tri-MB & Qua-MB & Apt-Qua-MB \\
\hline $\begin{array}{c}\text { Cells } \\
\text { percentage (\%) }\end{array}$ & 0 & 0.08 & 96.61 & 1.13 & 97.11 \\
\hline
\end{tabular}

Figure S12. The cellular uptake of Apt-Tri-MB-Cy5 (A) and Apt-Qua-MB-Cy5 (B) explored by flow cytometry. (C) The positive cell percentage (PCP) estimate from Cell ${ }_{\mathrm{p}} / \mathrm{Cell}_{\mathrm{t}} \times 100 \%$, where Cell $\mathrm{p}$ and Cell $\mathrm{t}$ denote the number of positive cells that internalized DNA nanoassemblies and the total number of cells, respectively. The $\mathrm{PCP}$ in the absence of DNA assemblies is normalized to $0(\%)$.

\section{Experimental procedure:}

MCF-7 cells were seeded on 12-well plates and cultured for $24 \mathrm{~h}$. The cells were separately incubated with Apt-Tri-MB-Cy5, Tri-MB-Cy5, Apt-Qua-MB-Cy5 and Qua-MB-Cy5 (the final concentration of each one, $50 \mathrm{nM}$ ) for $4 \mathrm{~h}$. Then, the cells were harvested with $0.25 \%$ trypsin and washed with normal saline. After suspending the cells in $400 \mu \mathrm{L}$ of saline, the resulting solution is ready for flow cytometry analysis (Cytoflex, Beckman Coulter). The fluorescence intensity of the cells was analyzed by counting 10000 cells under laser excitation of $638 \mathrm{~nm}$. Data analysis was performed via CytoFLEX software.

\section{Discussion:}

The cellular uptake of Apt-Tri-MB and Apt-Qua-MB were examined by flow cytometry. As shown in Figure S12, the fluorescence intensity of Apt-Tri-MB and Apt-Qua-MB are significantly higher than the control, demonstrating the efficient cellular internalization of Apt-Tri-MB and Apt-Qua-MB. Moreover, Panel C shows that Apt-Tri-MB and Apt-Qua-MB assemblies can be internalized into almost all cells. 


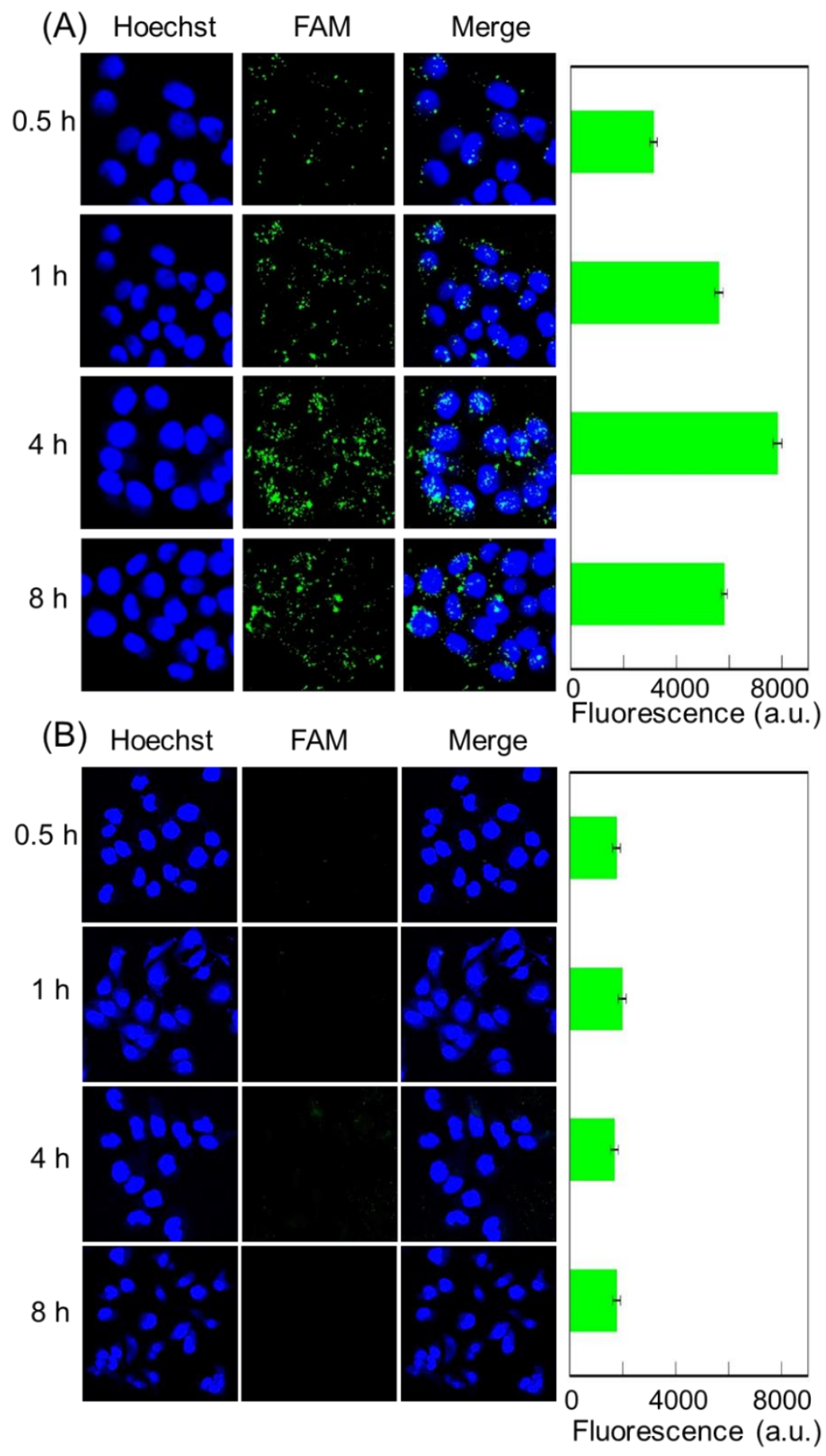

Figure S13. Confocal fluorescence imaging of miR-21 within MCF-7 (A) and L02 cells (B) treated with Lip-Tri-MB at different incubation times. The right panel: the corresponding quantitative fluorescence measurement. The FAM florescence originates from the opening of $\mathrm{MB}$ induced by hybridization with intracellular miR-21. Error bars are obtained from three independent parallel experiments.

\section{Discussion:}

As shown in Figure S13A, the FAM fluorescence intensity from MCF-7 cells 
increases with increasing the incubation time and reaches the maximum at $4 \mathrm{~h}$. In contrast, the FAM fluorescence intensity within L02 cells remains unchanged (Figure S13B) regardless of incubation time. It is evident that MCF-7 cells have the overexpressed miR-21 compared with L02.

\section{Experimental procedure:}

The MCF-7 cells were incubated with the Lip-Tri-MB (final concentration: $50 \mathrm{nM}$ ) for $0.5,1,4,8 \mathrm{~h}$. After washing by normal saline, to perform nuclear staining, the cells were incubated with $1 \mu \mathrm{M}$ Hoechst 33342 for $10 \mathrm{~min}$ and then washed with normal saline before imaging. Confocal imaging experiments were performed on laser scanning confocal microscope (Leica TCS SP8, Germany). As control, L02 cells were treated with Lip-Tri-MB under identical conditions. 


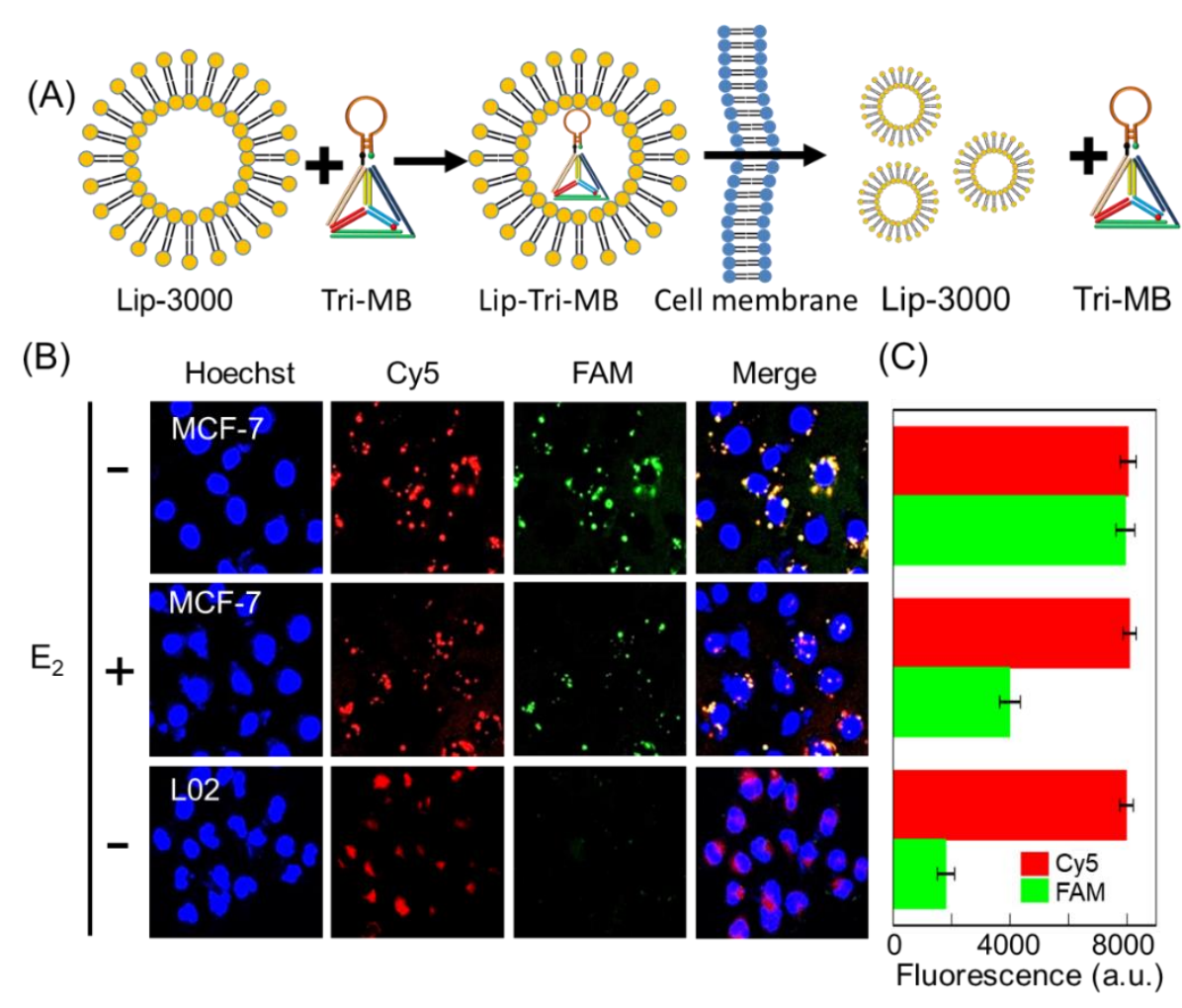

Figure S14. Tri-MB-based specific miRNA imaging inside living cells in the presence of transfection agents. (A) Schematic illustration of cellular internalization of Tri-MB with the help of Lip-3000. The Cy5 was attached to DNA triangle and was always in the ON state to image the cellular internalization of DNA nanoprobes. (B) Confocal fluorescence imaging of different expression levels of miRNA-21 in MCF-7 cells and L02 cells. For MCF-7, the upper panel indicates the normal cells, and the lower panel is the $E_{2}$-treated cells. (C) The quantitative fluorescence intensity from the confocal fluorescence images in (B). Error bars are obtained from three independent parallel experiments.

\section{Experimental procedure:}

The assembly of Tri-MB: seen in the section of 'Preparation of Tri-MB'.

Down-regulation of cellular miRNA: To down-regulate miR-21 expression, MCF-7 cells were treated by E2. More details, including cell imaging experiments, are seen in the section of 'Cell culture and confocal microscopy imaging'.

\section{Cell transfection:}

DNA molecular probes are hard to enter cell because of their poor cell permeability. Hence, Tri-MB assembly without active targeting moiety was transfected into target cells using Lip-3000 transfection reagent. The Lip-Tri-MB were prepared through mixing Tri-MB (final concentration: $50 \mathrm{nM}$ ) and Lip-3000 for $20 \mathrm{~min}$ at $37^{\circ} \mathrm{C}$ according to the instructions. For cell transfection experiments, all the cells, including L02, normal MCF-7 and $\mathrm{E}_{2}$-treated MCF-7, were incubated with the Lip-Tri-MB for 4 $\mathrm{h}$, followed by washing with saline. The capability of internalized Tri-MB to sense the intracellular miRNAs was evaluated via confocal fluorescence imaging of resulting 
cells according to the method described in the section of 'Cell culture and confocal microscopy imaging'.
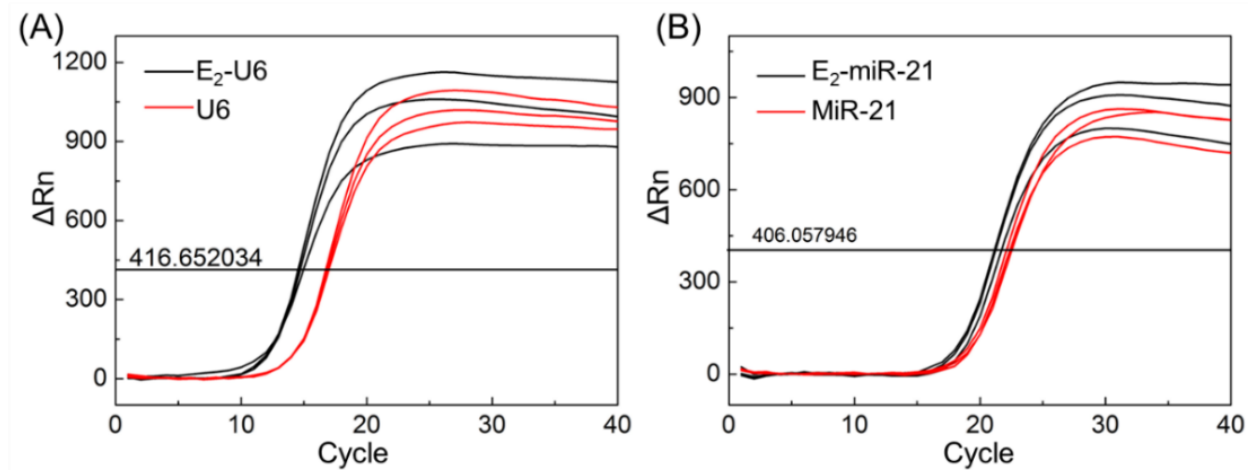

Figure S15. (A) qRT-PCR curves of U6 small RNA. (B) qRT-PCR curves of miR-21. The data were obtained from three parallel experiments. The black horizontal line is the threshold line, and the number on the line is the threshold value.

\section{Discussion:}

As shown in Figure S15 and in Table S2. The relative expression level of miR-21 in $\mathrm{E}_{2}$-treated MCF-7 cells is about 0.43 compared with its expression amount (EA) in native MCF-7 cells. If the EA in native MCF-7 cells is defined as 1 , the measured value of 0.44 obtained by Apt-Tri-MB is better than 0.50 offered by Lip-3000-transfection-based Tri-MB. Possibly, Lip-3000-mediated transfection could drive excessive amount of $\mathrm{MB}$ probes enter target cells, leading to the increase of fluorescence background and thereby compromising the cell imaging ability of MB. In contrast, incorporation of aptamer AS1411 to Tri-MB endows probes with active tumor-targeting capability, improving the cell imaging performance. 


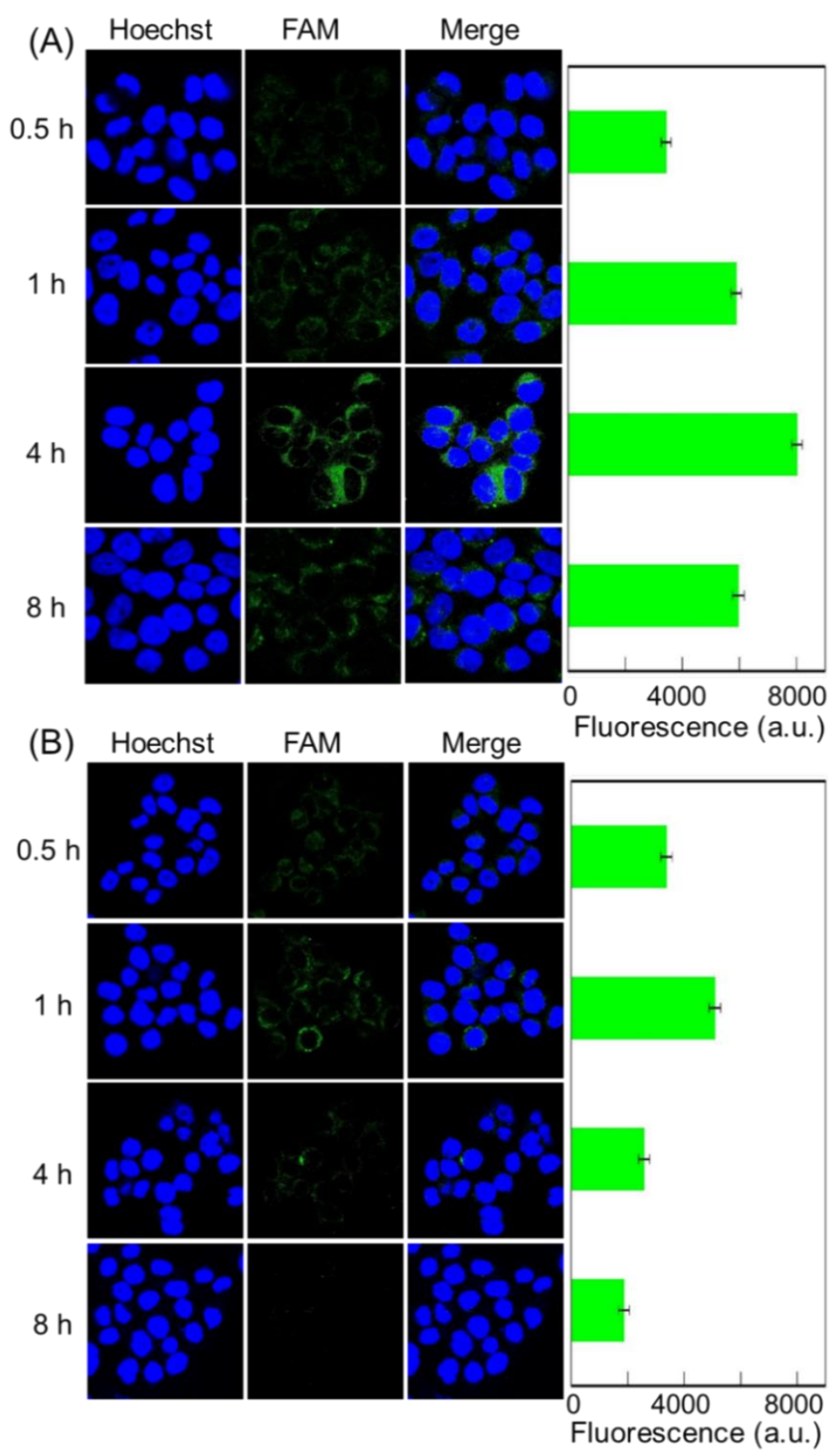

Figure S16. Intracellular stability of Apt-tri-MB. Confocal fluorescence images of MCF-7 cells treated by Apt-Tri-MB-F (A) and Apt-MB-F (B) at different incubation times. The right part: the corresponding quantitative fluorescence measurement. For Apt-tri-MB-F and Apt-MB-F, the MB was substituted with MB-F that is always in the ON state because of the lack of quencher. Error bars are obtained from three independent parallel experiments.

\section{Experimental procedure:}

Two types of MCF-7 cells were separately incubated with Apt-Tri-MB-F (the final concentration: $50 \mathrm{nM}$ ) and Apt-MB-F (the final concentration: $50 \mathrm{nM}$ ) for $0.5,1,4$ or 
$8 \mathrm{~h}$, respectively. After washing by normal saline, to perform nuclear staining, the cells were incubated with $1 \mu \mathrm{M}$ Hoechst 33342 for $10 \mathrm{~min}$ and washed with normal saline before imaging. Confocal imaging experiments were performed on laser scanning confocal microscope. 


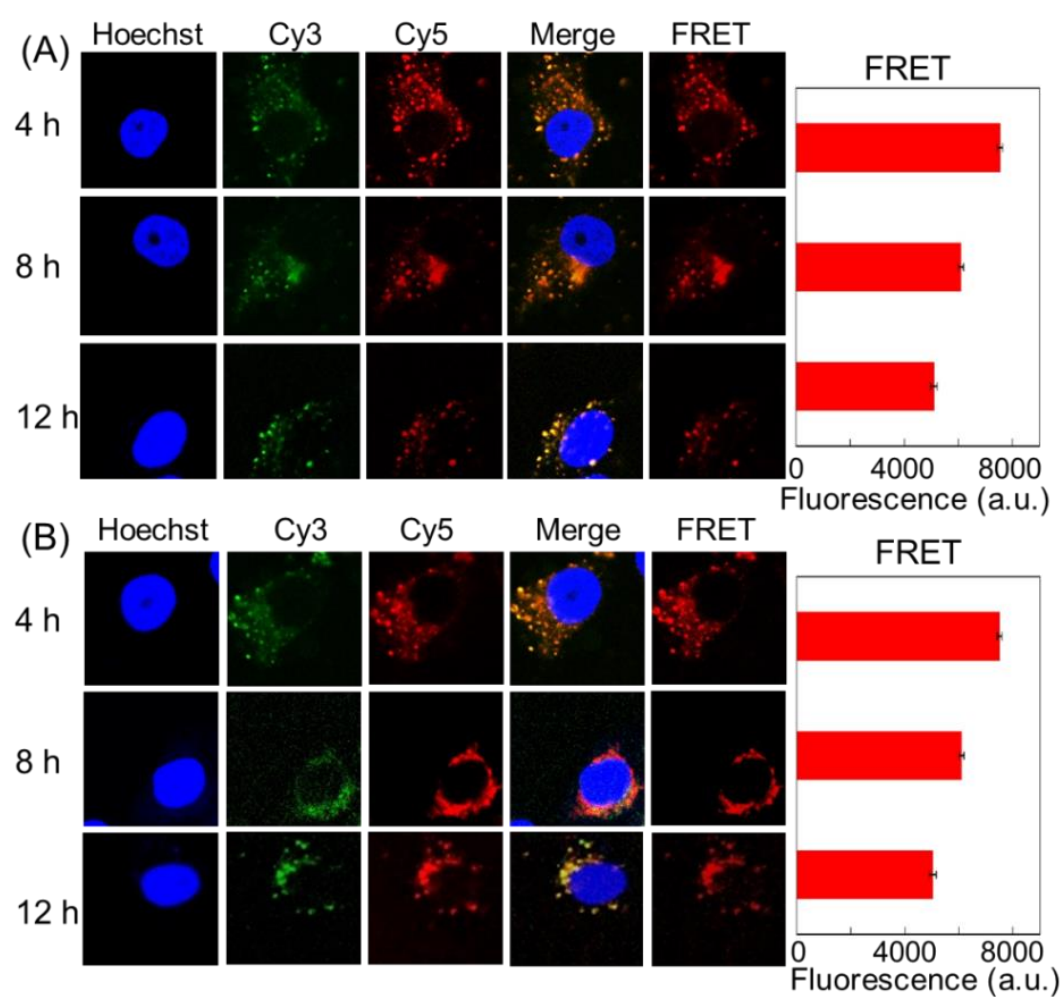

Figure S17. Intracellular stability of Apt-Tri-MB and Apt-Qua-MB. Confocal fluorescence images of MCF-7 cells incubated with Apt-Tri-MB-FRET (A) and Apt-Qua-MB-FRET (B) for different incubation time periods. The Merge image is obtained by overlaying green from $\mathrm{Cy} 3$ and red from Cy5. The right part: the quantitative fluorescence resonance energy transfer (FRET). Error bar is obtained from three independent parallel experiments.

\section{Experimental procedure:}

MCF-7 cells were incubated with Apt-Tri-MB-FRET (final concentration: $50 \mathrm{nM}$ ) or Apt-Qua-MB-FRET (final concentration: $50 \mathrm{nM}$ ) for 4,8 or $12 \mathrm{~h}$. After washing by normal saline, the cells were incubated with $1 \mu \mathrm{M}$ Hoechst 33342 for $10 \mathrm{~min}$ to execute nuclear staining, followed by washing with normal saline again. Confocal imaging experiments were performed on laser scanning confocal microscope. For the FRET image, the excitation wavelength was set at $552 \mathrm{~nm}$ and the emission spectrum was collected from $650-730 \mathrm{~nm}$, which are the same as the excitation wavelength of $\mathrm{Cy} 3$ and emission range of $\mathrm{Cy} 5$, respectively.

\section{Discussion:}

To assess the intracellular stability of DNA nanostructures, Apt-Tri-MB-FRET and Apt-Qua-MB-FRET were assembled, and their DNA components are shown in Table S5. For the two intact DNA nanoassemblies, the energy transfer from the photo-excited donor $\mathrm{Cy} 3$ to the acceptor $\mathrm{Cy} 5$ can occur, generating the FRET signal. Because the highest fluorescence signal of DNA nanoassembles is detected at 4-h incubation, we examined the FRET signal change after 4-h incubation of cells with 
the probes. As shown in Figure S17, one can see that the green fluorescence from $\mathrm{Cy} 3$ overlaps with red fluorescence from $\mathrm{Cy} 5$ and high FRET signal is detected, demonstrating that the Apt-Tri-MB and Apt-Qua-MB can preserve the structural integrity after being internalized into living cells. If the fluorescence intensity of FRET signal at $4 \mathrm{~h}$ was defined as $100 \%$, even if incubating for $12 \mathrm{~h}$, about $70 \%$ FRET signal can be still retained. 


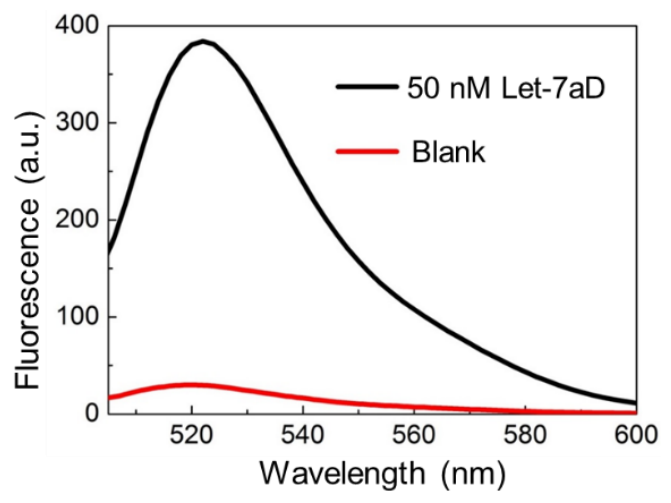

Figure S18. Fluorescence spectra to assess the feasibility of Apt-Tri-MB-7a for the Let-7a detection.

\section{Experimental procedure:}

Apt-Tri-MB-7a ( $25 \mu \mathrm{L}, 0.4 \mu \mathrm{M}$, adjusted to $199 \mu \mathrm{L}$ with $1 \times \mathrm{TE}$ buffer $)$ was incubated with DNA analogue of Let-7a $(1 \mu \mathrm{L}, 10 \mu \mathrm{M})$ or the same volume of $1 \times \mathrm{TE}$ buffer (Blank in the absence of target miRNA) at $37^{\circ} \mathrm{C}$ for $2 \mathrm{~h}$. Then, the fluorescence spectra of resulting solution were collected. The parameter setting was described in the section of 'Fluorescence detection'. 


\section{Supplementary References}

1. Xi, Q.; Zhou, D. M.; Kan, Y. Y.; Ge, J.; Wu, Z. K.; Yu, R. Q.; Jiang, J. H., Highly sensitive and selective strategy for microRNA detection based on WS2 nanosheet mediated fluorescence quenching and duplex-specific nuclease signal amplification. Anal. Chem. 2014, 86, 1361-1365.

2. Ouyang, W.; Liu, Z.; Zhang, G.; Chen, Z.; Guo, L.; Lin, Z.; Qiu, B.; Chen, G., Enzyme-free fluorescent biosensor for miRNA-21 detection based on $\mathrm{MnO} 2$ nanosheets and catalytic hairpin assembly amplification. Anal. Methods 2016, 8, 8492-8497.

3. Hu, Y.; Zhang, L.; Zhang, Y.; Wang, B.; Wang, Y.; Fan, Q.; Huang, W.; Wang, L., Plasmonic nanobiosensor based on hairpin DNA for detection of trace oligonucleotides biomarker in cancers. ACS Appl. Mater. Inter. 2015, 7, 2459-2466.

4. Causa, F.; Aliberti, A.; Cusano, A. M.; Battista, E.; Netti, P. A., Supramolecular spectrally encoded microgels with double strand probes for absolute and direct miRNA fluorescence detection at high sensitivity. J. Am. Chem. Soc. 2015, 137, 1758-1761.

5. Zhou, W.; Li, D.; Xiong, C.; Yuan, R.; Xiang, Y., Multicolor-Encoded Reconfigurable DNA Nanostructures Enable Multiplexed Sensing of Intracellular MicroRNAs in Living Cells. ACS Appl. Mater. Inter. 2016, 8, 13303-13308.

6. Wu, C.; Cansiz, S.; Zhang, L.; Teng, I. T.; Qiu, L.; Li, J.; Liu, Y.; Zhou, C.; Hu, R.; Zhang, T., A Nonenzymatic Hairpin DNA Cascade Reaction Provides High Signal Gain of mRNA Imaging inside Live Cells. J. Am. Chem. Soc. 2015, 137, 4900-4903.

7. Tay, C. Y.; Yuan, L.; Leong, D. T., Nature-Inspired DNA Nanosensor for Real-Time in Situ Detection of mRNA in Living Cells. ACS Nano 2015, 9, 5609-5617.

8. Lei, Y.; Qiao, Z.; Tang, J.; He, X.; Shi, H.; Ye, X.; Yan, L. a.; He, D.; Wang, K., DNA nanotriangle-scaffolded activatable aptamer probe with ultralow background and robust stability for cancer theranostics. Theranostics 2018, 8, 4062-4071.

9. Khalil; Abnous; Noor; Mohammad; Danesh; Mohammad; Ramezani; Fahimeh; Charbgoo; Amirhossein, Targeted delivery of doxorubicin to cancer cells by a cruciform DNA nanostructure composed of AS1411 and FOXM1 aptamers. Expert Opin. Drug Del. 2018, 15, 1045-1052.

10. Peng; Ruizi; Zheng; Xiaofang; Lyu; Yifan; Xu; Liujun; Zhang; Xiaobing, Engineering a 3D DNA-Logic Gate Nanomachine for Bispecific Recognition and Computing on Target Cell Surfaces. J. Am. Chem. Soc. 2018, 140, 9793-9796.

11. Walsh, A. S.; Yin, H. F.; Erben, C. M.; Wood, M. J. A.; Turberfield, A. J., DNA Cage Delivery to Mammalian Cells. ACS Nano 2011, 5, 5427-5432.

12. Ma, Y.; Zheng, H.; Wang, C.; Yan, Q.; Chao, J.; Fan, C.; Xiao, S.-J., RCA Strands as Scaffolds To Create Nanoscale Shapes by a Few Staple Strands. J. Am. Chem. Soc. 2013, 135, 2959-2962.

13. Mou, Y.; Yu, J.-Y.; Wannier, T. M.; Guo, C.-L.; Mayo, S. L., Computational design of co-assembling protein-DNA nanowires. Nature 2015, 525,230-233.

14. Nasongkla, N.; Shuai, X.; Ai, H.; D. Weinberg, B.; Pink, J.; A. Boothman, D.; 
Gao, J., cRGD-Functionalized Polymer Micelles for Targeted Doxorubicin Delivery. Angew. Chem. 2004, 116, 6483-6487.

15. Zhang, C. Y.; Johnson, L. W. Quantum dot-based fluorescence resonance energy transfer with improved FRET efficiency in capillary flows. Anal. Chem. 2006, 78, $5532-5537$. 